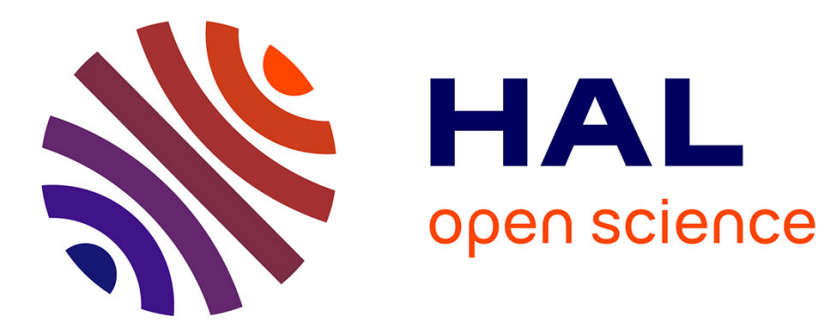

\title{
Does single monetary policy have asymmetric real effects in EMU? \\ Marilyne Huchet
}

\section{To cite this version:}

Marilyne Huchet. Does single monetary policy have asymmetric real effects in EMU?. Journal of Policy Modeling, 2003, 25 (2), pp.151-178. 10.1016/S0161-8938(02)00204-1 . halshs-00143785

\section{HAL Id: halshs-00143785 https://shs.hal.science/halshs-00143785}

Submitted on 26 Apr 2007

HAL is a multi-disciplinary open access archive for the deposit and dissemination of scientific research documents, whether they are published or not. The documents may come from teaching and research institutions in France or abroad, or from public or private research centers.
L'archive ouverte pluridisciplinaire HAL, est destinée au dépôt et à la diffusion de documents scientifiques de niveau recherche, publiés ou non, émanant des établissements d'enseignement et de recherche français ou étrangers, des laboratoires publics ou privés. 


\title{
Does single monetary policy have asymmetric real effects in EMU?
}

\author{
Marilyne Huchet ${ }^{1}$
}

\begin{abstract}
:
This article compares reactions of economies in Economic Monetary Union to a single monetary policy. For that, we estimate a reaction function supposed to represent the behaviour of European Central Bank over the period 1980-1998. Then residuals are introduced into the production equation of each country. We break up monetary shocks in two axes: first, anticipated against unanticipated shocks and then positive against negative shocks. These distinctions permit a best evaluation of the degree of homogeneity of the effects of monetary policy. France, Germany, Spain and Austria seem more sensitive to unanticipated interest rates increases contrary to Belgium and Italy. These results illustrate all the problem of single monetary policy.
\end{abstract}

JEL classification: C2, E5.

Keywords: monetary policy shocks, reaction function, asymmetric effects, Economic Monetary Union.

\footnotetext{
${ }^{1}$ CREREG - Faculté des Sciences Économiques - 7, place Hoche - CS 86514 - 35065 RENNES Cedex (France).Tel.+33 223233587 ; Fax: +3329938 8084 . E-mail: marilyne.huchet@univ-rennes1.fr.

I thank Jean-Jacques Durand and Nathalie Payelle for their helpful comments.
} 


\section{INTRODUCTION}

January 1st, 1999 is now a key date in modern history. Indeed, it points the transition to the third phase of the Maastricht's Treaty signed in 1992: founding of the Economic and Monetary Union and creation of a single currency, the Euro, within this zone. The change from national monetary policies directed by various independent central banks to a single monetary policy led by only one entity, the European Central Bank (ECB), raises some questions. Monetary authorities fear the existence of asymmetries in the reactions of various economies to a major monetary adjustment assumed to be symmetric since decided by the ECB. That would create tensions, would lead to expensive real adjustments given the impossibility of exchange rate adjustments. Indeed, the success in leading a single monetary policy depends not only on nominal convergence, which is considered successful globally, but also on the convergence of national economies sensitivity degrees to measurements of monetary regulation. Without such a convergence, a common monetary impulse could have different effects on national countries and could become an asymmetric shock. These questions are significant because they raise the problem of monetary policy control by the ECB. A common interest rate change will produce an uneven distribution of output across the monetary union.

The aim of this work is, precisely, to measure the reactions of European economies to a single monetary shock and to determine whether common shocks of monetary policy induce asymmetric reactions on real activity in each country. To undertake this analysis, we choose a similar model to that used by Cover (1992): we first estimate the reaction function of the ECB and then, in a second stage, the production equation for each European economy. The advantages compared to the vector autoregression (VAR) systems are mainly on two levels. First of all, Cover's method enables to take into account the unanticipated part of monetary policy. Then, analyses on VAR systems are all based on an assumption of linearity and symmetry of the effects of currency on the activity whereas macroeconomic theory generally shows that these effects can be asymmetric (downward price inflexibility). We apply this analysis to the Union including eight countries (EMU without Greece, Portugal, Luxemburg and Ireland) over the period 1980-1998. We take into account two kinds of asymmetries to know whether countries react in the same way to shocks. First of all, we investigate whether or not output asymmetrically responds either to anticipated component or unanticipated monetary shocks or to both. Lastly, we examine their reactions to positive and negative shocks. Taken all together, our results suggest symmetry in the reactions of European economies with regard to the first distinction: only unanticipated single monetary policy can be considered to have real effects on the production 
of European countries. Nevertheless, a relative asymmetry exists concerning the distinction between effects of an expansionist or restrictive monetary policy, as some countries react more to unanticipated interest rate increases and others to falls.

In the following section, the monetary policy led by the ECB is examined and represented in a model. We then attempt to quantify the real effects of this single monetary policy on European economies and to clarify the implications for ECB policy.

\section{ECONOMIC MODEL}

Our model includes a monetary policy equation, a reaction function supposed to represent the behaviour of the ECB, as well as activity equations. Before describing our modelling approach, we first need to outline the ECB' s single monetary policy ${ }^{2}$.

\subsection{ECB's single monetary policy}

The strategy of monetary policy implemented by Eurosystem ${ }^{3}$ is based on a primary objective and two pillars to achieve this goal.

\subsubsection{Primary objective of the single monetary policy: price stability}

According to article 105 (1) of the Treaty, "the principal objective of the ESCB is to maintain price stability". The choice of this objective builds on the conviction that a monetary policy preserving price stability in a durable and credible way makes the best total contribution to improving economic prospects and raising the living standards of citizens. The Council of governors of the ECB has adopted the following definition: " the price stability is defined like a progression over one year of the harmonized index of consumer prices $\left(\mathrm{HICP}^{4}\right)$ lower than $2 \%$ in the Euro zone ". According to this definition, price stability " is to be maintained over the medium term ".

\footnotetext{
${ }^{2}$ ECB (2001).

${ }^{3}$ The Eurosystem differs from the European System of Central Banks owing to the fact that it includes only national central banks of member countries inside EMU; the ECB also belongs to it.

${ }^{4}$ Data about this index are available only since 1990.
} 


\subsubsection{Role of money}

According to the ECB, money constitutes a natural, solid and reliable " nominal anchor point " for a monetary policy focused on the bearing of price stability. A follow-up of monetary aggregates helps to identify the nature of shocks affecting the economy and thus contributes to the evaluation of overall economic changes. The Eurosystem then had to choose the monetary aggregate to use. Statistical data, though often dubious, were considered to be sufficiently conclusive to justify the announcement of a reference value fixed at $4,5 \%$ per annum for the growth of the broad monetary aggregate, M3. However, the ECB does not attempt to keep monetary growth at the reference value at any particular point in time by manipulating interest rates. This is one of the great differences between setting a reference value and announcing an intermediate monetary objective.

\subsubsection{Economic indicators outlook}

The range of indicators in question includes many variables having some properties of advanced indicators of the future price trend. The most complete measure of total conditions of supply and demand is the difference between effective and potential levels of global economy production, i.e. "the output gap". The evolution of potential production can be defined starting from the growth rate of real GDP bearable in medium term. Its evolution is determined by the increase in capital stock and labour supply, and by the productivity growth rate. If the actually recorded output rise is higher than the potential growth level, there could follow a positive output gap likely to lead to inflationary tensions. Conversely, if the effective growth rate is lower than its potential level. However, this output gap can be used at most only as an additional indicator because it is difficult to determine in a precise way the level of potential production and consequently the extent of the output gap.

\subsection{Choice of reaction function}

\subsubsection{A brief overview of literature}

The debate rules versus discretion gave place to multiple developments. Many authors endeavour to propose an activist rule for central banks with regard to the inflation objective. From this abundant literature, two principal activist rules are highlighted. The first recommended by McCallum $(1987,1988,1993,1995)$ is a rule in terms of nominal GDP: the central Bank intervenes on the level of monetary base according to the gap between the nominal GDP and its objective. The second has been presented by Taylor (1993) for the case of the United States over 
1987-1992: the central bank handles the interest rate according to both the output and inflation gaps. Jaillet (1998) introduces it again in a clear and interesting way, as does Verdelhan (1999) from a European point of view.

However, these rules present a number of limits. McCallum's rule refers to a particular institutional context where authorities can control the monetary base. That is certainly possible in the United States but it's generally judged that this rule is not fitted to the European institutional context where authorities use the interest rates as instruments of their policy. Therefore some adjustments must be made before one can consider it seriously as a guide for the actions of the ECB. As regards Taylor's rule, there are in particular uncertainties as to the determination of the levels of real neutral interest rate and of output gap. These boundaries show the risk that divergent recommendations of monetary policy may be reached.

\subsubsection{Specification of a reaction function for the ECB: a positive approach}

We estimate a reaction function, which treats nominal short-term interest rate as the instrument of monetary policy. Thus nominal interest rate in the short run constitutes the endogenous variable of this equation since we consider that the ECB handles it according to the state of the economy. It is clearly necessary to determine what overall information on the state of the economy the Central Bank is expected to react to. The difficulty is due to the lack of experience on the transmission channel for the common monetary policy in EMU and to inescapable uncertainties about this mechanism. The introduction of a new common currency is a major structural change in the economic structure of EMU. In addition, this rate can appear in level or first difference according to the integration order obtained but also according to the most adapted choices concerning the practice of the ECB. We use the interest rate in level. This choice is explained on the one hand by the policy followed by the ECB but also by the statistical analyses carried out such as augmented Dickey-Fuller tests of unit roots, tests of presence of a deterministic trend by Stock and Watson (1989) and break tests by Perron $(1989,1997)^{5}$. Results to these tests suggest that interest rate is first order integrated, i.e. that the contemporary variable is directly explained by its past but it displays a break in 1988:3. The series of interest rate can thus be viewed as null order integrated, i.e. stationary, on the two sub periods. Moreover, it can also appear with a lag as an explanatory variable because of smoothing of the interest rates. Indeed, facing great monetary shocks during the eighties because of development of

\footnotetext{
${ }^{5}$ See appendix 1.
} 
financial innovations, monetary authorities have adopted operational procedures designed to smooth interest rate fluctuations on the inter bank market.

The existing consensus on final inflation objective removes any suspicion concerning the introduction of inflation as an explanatory variable in the reaction function of the ECB. Nevertheless the question arises if we introduce the inflation rate or inflation gap compared to its objective which is laid down at $2 \%$ by the ECB. This second solution appears more appropriate to the policy of the ECB.

Output gap often appears in the studies as an explanatory variable of the interest rate. It seems that this variable does not appear clearly as an ECB objective but it is however quoted in the second pillar of the monetary policy followed in phase III. Although the ECB clearly gives priority to the objective of inflation, we can assume that it is also bent on supporting activity growth when price stability is attained.

In addition, with the announcement of a reference value for the growth of the broad monetary aggregate M3, monetary policy strategy of the ECB assigns a dominant role to money. This aggregate " is harmonised " for the whole of the EMU and there is a " reference value ". This careful decision is probably explained by uncertainties relating to the relation between monetary aggregates and future inflation in the economy. The choice of a broad aggregate (broader than that retained in France) permits to take into account substitution effects related to financial innovations which can only multiply in the Euro zone. The reference value is fixed at 4,5\% per annum for the first two years of operation of the ESCB.

From these criteria, the following reaction function is supposed to represent the behaviour of the ECB:

$$
\mathrm{i}_{\mathrm{t}}^{\mathrm{A}}=\operatorname{cste}+\alpha \mathrm{i}_{\mathrm{t}-1}^{\mathrm{A}}+\beta\left(\pi_{\mathrm{t}}^{\mathrm{A}}-\pi^{*}\right)_{\mathrm{t}-1}+\delta\left(\Delta \mathrm{m} 3_{\mathrm{t}}^{\mathrm{A}}-\Delta \mathrm{m} 3^{*}\right)_{\mathrm{t}-1}+\gamma \mathrm{y}_{\mathrm{t}-1}^{\mathrm{A}}+\varepsilon_{\mathrm{t}}
$$

Where $i_{t}^{A}$ is aggregate interest rate of the Union at time $t$, taken in level, $\pi_{t}^{A}$ is aggregate inflation rate of the Union at time $\mathrm{t}, \pi^{*}$ is the objective inflation rate set at $2 \%$ per annum, $\Delta \mathrm{m} 3_{\mathrm{t}}^{\mathrm{A}}$ is aggregate growth rate of M3 at time $\mathrm{t}, \Delta \mathrm{m} 3^{*}$ is the reference value for this aggregate $\mathrm{M} 3$ growth fixed at $4,5 \%$ per annum, $\mathrm{y}_{\mathrm{t}-1}^{\mathrm{A}}$ is the output gap $\left(\mathrm{Y}_{\mathrm{t}}-\mathrm{Y}_{\text {potential }}\right) / \mathrm{Y}_{\mathrm{t}}$ with $\mathrm{Y}$ the real GDP, at $\mathrm{t}-1$. Potential GDP is approached by the Hodrick-Prescott filter; $\varepsilon_{\mathrm{t}}$ is an error term assumed to be uncorrelated with any available information. 
Equation (1) describes how the ECB controls interest rate according to the state of economy given by the interest rate, the inflation gap, the growth gap of M3 and by the output gap, all these explanatory variables being one period lagged. Error terms resulting from this estimation, $\varepsilon_{t}$, are interpreted as the unanticipated shocks. The difference between the variable of monetary policy, $\mathrm{i}_{\mathrm{t}}^{\mathrm{A}}$, and this series of shocks then represents the anticipated part of monetary policy: it is noted $\hat{\mathrm{i}}_{\text {anti, }}$

$$
\hat{\mathrm{i}}_{\mathrm{anti}, \mathrm{t}}=\mathrm{cs} \mathrm{ste}+\hat{\alpha} \mathrm{i}_{\mathrm{t}-1}^{\mathrm{A}}+\hat{\beta}\left(\pi_{\mathrm{t}}^{\mathrm{A}}-\pi^{*}\right)_{\mathrm{t}-1}+\hat{\delta}\left(\Delta \mathrm{m} 3_{\mathrm{t}}^{\mathrm{A}}-\Delta \mathrm{m} 3^{*}\right)_{\mathrm{t}-1}+\hat{\gamma} \mathrm{y}_{\mathrm{t}-1}^{\mathrm{A}}
$$

These two series are also broken up in positive and negative effects in order to give a best evaluation of the feasible asymmetric effects:

$$
\begin{array}{lll}
\varepsilon^{+}=\max (\varepsilon, 0) & \text { or } & \varepsilon_{\mathrm{t}}{ }^{+}=0,5\left[\operatorname{abs}\left(\varepsilon_{\mathrm{t}}\right)+\varepsilon_{\mathrm{t}}\right] \\
\varepsilon^{-}=\min (\varepsilon, 0) & \text { or } & \varepsilon_{\mathrm{t}}{ }^{-}=-0,5\left[\operatorname{abs}\left(\varepsilon_{\mathrm{t}}\right)-\varepsilon_{\mathrm{t}}\right] \\
\hat{\mathrm{i}}_{\text {anti }}{ }^{+}=\max \left(\hat{\mathrm{i}}_{\text {anti }}, 0\right) & \text { or } & \hat{\mathrm{i}}_{\text {anti, t }}{ }^{+}=0,5\left[\operatorname{abs}\left(\hat{\mathrm{i}}_{\text {anti, }}\right)+\hat{\mathrm{i}}_{\text {anti,t }}\right] \\
\hat{\mathrm{i}}_{\text {anti }}{ }^{-}=\min \left(\hat{\mathrm{i}}_{\text {anti }}, 0\right) & \text { or } & \hat{\mathrm{i}}_{\text {anti,t }}{ }^{-}=-0,5\left[\operatorname{abs}\left(\hat{\mathrm{i}}_{\text {anti,t }}\right)-\hat{\mathrm{i}}_{\text {anti,t }}\right]
\end{array}
$$

Definition of these positive and negative money-supply shocks is essential. It is significant to note that a rise of interest rate decided by the ECB (positive money-supply shock) is interpreted here as a restrictive monetary policy. Conversely, a negative monetary shock corresponds to a fall in interest rate i.e. to an expansionist monetary policy. These series are then used as explanatory variables in output process to evaluate their impacts on the activity of economies.

\subsection{Output equation for each European economy}

The purpose of this production equation for each European economy is to answer to a quite precise question: are effects of single monetary policy different on production according to countries in EMU?

\subsubsection{Anticipated versus unanticipated money}

According to Lucas (1973), anticipated monetary policy cannot have real effects: only unanticipated monetary policy shocks are likely to influence fluctuations in economic activity. This assumption of Lucas fits in 
with the New Classical School according to which money is neutral both in the short run and in the long run because the agents are not mistaken on average (hypothesis of rational anticipations).

However, the field of investigation of Lucas is not universally accepted. For instance, Romer and Romer (1989) support that anticipated or systematic monetary policy has stopped the post-war recessions in the United States. Monetarists have also built models in which anticipated monetary shocks can have real short-term effects. Mishkin (1982) showed that anticipated money supply growth rates have a significant impact on economic activity. Bernanke and Mihov (1995) and Cochrane (1995) also stressed the extent of the systematic component in monetary policy $^{6}$.

\subsubsection{Specification of production equations}

To limit divergent effects due to differences in models specification, we retain a similar model for all countries. We first of all define the lag length to use for production growth rates. This is done using a chronological univariate analysis with the Box-Jenkins approach (1970) to determine the data generating processes. The study of the autocorrelation correlograms and the partial autocorrelation correlograms of production growth rate for each country suggests us that those follow an AR(1) process. The output growth is regressed on its own past together with four lagged values of anticipated and/or unanticipated positive and negative monetary policy shocks. The introduced lags allow removing residuals autocorrelation but there is no consensual method to choose the optimal lags length to introduce. The adopted method here consists in sweeping k possible lags, generally ranging between 1 and $20^{7}$ and then to retain, among the lags which lead to some white noise residuals, that which minimises the forecast error. First of all, we use Ljung-Box ${ }^{8}$ criterion in order to determine whether the introduction of a given number of lags whitens random terms. If several models end in uncorrelated residuals, it is then necessary to keep the number whose introduction leads to the weakest forecast errors by means of $\mathrm{AIC}^{9}$ criterion (Akaike Information

\footnotetext{
${ }^{6}$ In addition, the possibility of asymmetry of the effects of anticipated policy was often more or less rejected because researchers used either the growth rate of M1 (Cover (1992) or the growth rate of M2 (De Long and Summers (1988)) as the monetary variable. It is then difficult to delimit asymmetries of effects of anticipated monetary policy since money growth has a great positive trend growth with few negative observations. We circumvent this limit by using the short-term interest rate.

${ }^{7}$ The upper limit of sweeping depends of the period length over which the empirical study is realised; in practice, one takes from $1 / 4$ to $1 / 3$ of the series.

$8 Q=T(T+2)\left(\sum_{j=1}^{K} \frac{r_{j}^{2}}{T-j}\right)$ where $\mathrm{r}_{\mathrm{j}}$ is the $\mathrm{j}^{\text {ith }}$ autocorrelation lag function of the residuals and $\mathrm{k}$ the lag length.

${ }^{9}$ Others use the FPE (Final Predictor Error). FPE $=(\mathrm{T}+\mathrm{k} / \mathrm{T}-\mathrm{k}) \sigma^{2}$.
} 
Criterion $^{10}$ ). The idea is to select the model which has the minimal loss of information (i.e. the smaller AIC). That leads to select the model with the smaller residual sum of squares or with the larger $\mathrm{R}^{2}$.

We consider the possibility that effects of a rise and a fall in interest rates are asymmetric. All too often, studies treating this question suppose symmetric effects. This assumption is too optimistic for various reasons and particularly owing to the fact that price flexibility is more significant upwards than downwards. To take into account asymmetries we study four different specifications of the activity equation. In equations (3) and (4), the objective is to see whether the monetary policy affects the real variables without making distinction between an expansionist or restrictive policy. We introduce the possibility of such an asymmetry into equations (5) and (6).

Equation taking into account only unanticipated policy with a symmetry constraint for unanticipated money-supply shocks:

$$
\Delta \mathrm{y}_{\mathrm{t}}=\text { constant }+\mathrm{a} \Delta \mathrm{y}_{\mathrm{t}-1}+\sum_{\mathrm{m}=1}^{\mathrm{k}} \mathrm{b}_{\mathrm{m}} \varepsilon_{\mathrm{t}-\mathrm{m}}+\mathrm{v}_{1 \mathrm{t}}
$$

Effects of anticipated and unanticipated shocks with symmetry constraint for positive/negative effects:

$$
\Delta \mathrm{y}_{\mathrm{t}}=\text { constant }+\mathrm{a} \Delta \mathrm{y}_{\mathrm{t}-1}+\sum_{\mathrm{m}=1}^{\mathrm{k}} \mathrm{b}_{\mathrm{m}} \varepsilon_{\mathrm{t}-\mathrm{m}}+\sum_{\mathrm{m}=1}^{\mathrm{k}} \mathrm{c}_{\mathrm{m}} \hat{\mathrm{i}}_{\mathrm{t}-\mathrm{m}}+\mathrm{v}_{2 \mathrm{t}}
$$

Unanticipated policy with assumption of asymmetry for positive and negative shocks:

$$
\Delta \mathrm{y}_{\mathrm{t}}=\text { constant }+\mathrm{a} \Delta \mathrm{y}_{\mathrm{t}-1}+\sum_{\mathrm{m}=1}^{\mathrm{k}} \mathrm{b}_{\mathrm{m}}^{+} \varepsilon_{\mathrm{t}-\mathrm{m}}^{+}+\sum_{\mathrm{m}=1}^{\mathrm{k}} \mathrm{b}_{\mathrm{t}-\mathrm{m}}^{-} \varepsilon_{\mathrm{t}-\mathrm{m}}^{-}+\mathrm{v}_{3 \mathrm{t}}
$$

Anticipated and unanticipated monetary policy with asymmetry assumption for positive/negative shocks:

$$
\Delta \mathrm{y}_{\mathrm{t}}=\text { constant }+\mathrm{a} \Delta \mathrm{y}_{\mathrm{t}-1}+\sum_{\mathrm{m}=1}^{\mathrm{k}} \mathrm{b}_{\mathrm{m}}^{+} \varepsilon_{\mathrm{t}-\mathrm{m}}^{+}+\sum_{\mathrm{m}=1}^{\mathrm{k}} \mathrm{b}_{\mathrm{t}-\mathrm{m}}^{-} \varepsilon_{\mathrm{t}-\mathrm{m}}^{-}+\sum_{\mathrm{m}=1}^{\mathrm{k}} \mathrm{c}_{\mathrm{m}}^{+} \hat{\mathrm{i}}_{\mathrm{t}-\mathrm{m}}^{+}+\sum_{\mathrm{m}=1}^{\mathrm{k}} \mathrm{c}_{\mathrm{m}}^{-} \hat{\mathrm{i}}_{\mathrm{t}-\mathrm{m}}^{-}+\mathrm{v}_{4 \mathrm{t}}
$$

\footnotetext{
${ }^{10} \mathrm{AIC}=\log (\mathrm{RSS} / \mathrm{T})+2 \mathrm{k} / \mathrm{T}$ where $\mathrm{T}$ is the number of observations, $\mathrm{k}$ the number of regressors and RSS the sum square residuals.
} 


\section{ACTIVITY OF COUNTRIES IN EMU}

Because of assumption that countries form an EMU over the period 1980/1998, we had to rebuild aggregate European series characteristic of this Monetary Union $^{11}$ in order to estimate a reaction function of the ECB common to all countries of Union.

\subsection{Aggregation techniques for national data and estimation}

\subsubsection{National data aggregation}

We suppose an Union with $\mathrm{n}$ countries, $\mathrm{i}=1 \ldots, \mathrm{n}$ and we deduce total real GDP of the Union in billion Euro $\left(\mathrm{GDP}^{\mathrm{A}}\right)$ as being the sum of the billion Euro real GDP of these $\mathrm{n}$ countries:

$\mathrm{GDP}^{\mathrm{A}}=\sum_{\mathrm{i}=1}^{\mathrm{n}} \mathrm{GDP}_{\mathrm{i}}$

We calculate the weight of GDP of each country i in the total real GDP of Union:

$$
\mathrm{p}_{\mathrm{i}}=\frac{\mathrm{GDP}_{\mathrm{i}}}{\sum_{\mathrm{i}=1}^{\mathrm{n}} \mathrm{GDP}_{\mathrm{i}}} \quad \text { with } \quad \sum_{\mathrm{i}=1}^{\mathrm{n}} \mathrm{p}_{\mathrm{i}}=1
$$

We can then rebuild the aggregate series of GDP, interest rate, inflation rate and money supply:

$$
\begin{array}{ll}
\Delta \mathrm{gdp}^{\mathrm{A}}=\sum_{\mathrm{i}=1}^{\mathrm{n}} \mathrm{p}_{\mathrm{i}} \Delta \mathrm{gdp}_{\mathrm{i}} & \mathrm{i}_{\mathrm{ct}}^{\mathrm{A}}=\sum_{\mathrm{i}=1}^{\mathrm{n}} \mathrm{p}_{\mathrm{i}} \mathrm{i}_{\mathrm{ct}, \mathrm{i}} \\
\operatorname{ir}^{\mathrm{A}}=\sum_{\mathrm{i}=1}^{\mathrm{n}} \mathrm{p}_{\mathrm{i}} \mathrm{ir}_{\mathrm{i}} & \Delta \mathrm{m}^{\mathrm{A}}=\sum_{\mathrm{i}=1}^{\mathrm{n}} \mathrm{p}_{\mathrm{i}} \Delta \mathrm{m}_{\mathrm{i}}
\end{array}
$$

Where $g d p^{\mathrm{A}}, \mathrm{i}_{\mathrm{ct}}^{\mathrm{A}}, \mathrm{ir}^{\mathrm{A}}$ and $\mathrm{m}^{\mathrm{A}}$ represent respectively billion Euro aggregate GDP $(\log )$, short term aggregate interest rate in $\%$, aggregate inflation rate $(\%)$ and aggregate money-supply $(\log )$ in Euro billions. These variables preceded by $\Delta$ represent these same variables in growth rates.

\footnotetext{
${ }^{11}$ Data are discussed in appendix 1.
} 
The analysis of evolution of the sum of GDP of Union with eight countries with that of the GDP of EMU with twelve countries published by the OECD shows that the sample of countries forming our Union is very representative of the EMU. In the same way, it is possible to check the accuracy of some aggregate series like GDP growth rate, inflation rate as well as M3 growth ${ }^{12}$. Indeed, the OECD publishes historical series for GDP and inflation rate of EMU and the ECB publishes also a retrospective series for M3. We can thus easily check that these series merge or almost and thus, that our aggregate series represent the EMU as accurately as possible. From the total GDP of the union with eight countries and from each one of national GDP, it is then possible to calculate the share of GDP for each country in this union. The obtained weights are the following:

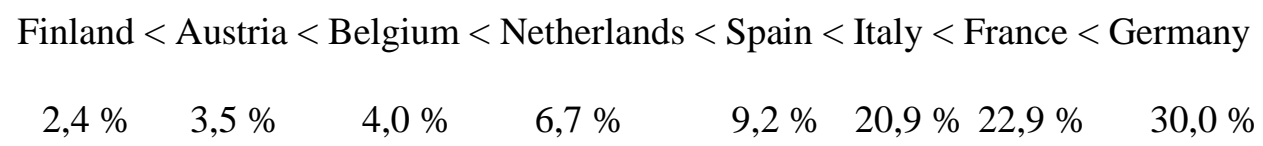

We check without difficulty the stability of these weights on the studied period, Germany being always the most significant country in terms of GDP and Finland the smallest. Our analysis seems reliable since the obtained weights are connected with those used in other studies such as Gerlach and Schnabel (1999). The possible advantage of such an aggregate model is that spill over effects between countries can be cancelled and these errors in national forecasts can then disappear in the aggregate forecast. It is clear that our analysis comes up against the Lucas criticism to a certain extent. However, experiment shows that phenomena of " memory " play a great role in monetary and financial matters and that major institutional reforms as for example the EMU do not permit to erase traces of the past quickly. Moreover, even if conversion of the European Monetary System into Economic Monetary Union shows a major change in system, it does not reduce the significance of data for years under the EMS as they contain useful information for the ECB.

\subsubsection{Estimation}

Tests of augmented Dickey-Fuller are performed on national and aggregate series ${ }^{13}$. The inflation rate (or the inflation gap compared to its objective) is one order integrated within sight of tests. However, unit root tests are renowned for their weak capacity for rather small samples of data like ours. Moreover the economic foundations

\footnotetext{
${ }^{12}$ Graphs are available near the author.

${ }^{13}$ See conclusions reported from calculations in the table 1 of section 12 - in appendix 1.
} 
encourage us to choose the inflation gap into the reaction function even if it contains a unit root. As for the interest rate, the results have already been mentioned. It contains a unit root over the whole period but the existence of a break lets us think that it can be supposed stationary over the two sub-periods. We take the interest rate in level. The aggregate GDP as well as the national GDP contain a unit root: they are thus stationary in first difference. The aggregate money supply M3 is one order integrated with a trend. Output gap of the Union is stationary. Tests of heteroscedasticity, non autocorrelation and specification error were carried out. Estimate of various specifications by ordinary least squares equation by equation (OLS) and then by non linear generalised least squares (NLGLS) for the two last specifications ${ }^{14}$ enables us to ensure robustness of the results as far as possible. To test the significant effects and asymmetric effects of monetary policy, we implement various tests ${ }^{15}$ :

- $\quad$ test of equality of coefficient to test the asymmetry between positive and negative effects

- test of significativity of the sum of coefficients

- test of equality of coefficients to judge the extent of impacts of anticipated/unanticipated money on the activity

- $\quad$ test of nullity of coefficients

- $\quad$ joint test of anticipated and unanticipated money effects

\subsection{Results}

As we have already specified, if reactions of national European economies to a common change of interest rate are strongly differentiated, the implementation of a strategy in the zone then becomes delicate. This risk is all the more difficult to appreciate because of structural changes on goods and labour markets as well as on financial markets. From this point of view, our study certainly shows a limit since it is based on the latest historical data not integrating the modifications fully related to the move into EMU. It is the famous Lucas' criticism! However it is possible to assert that significant transmission channels have already disappeared: exchange rate fluctuations, interest rate gaps, exchange rate risk premiums (which had already started with financial convergence).

\footnotetext{
${ }^{14}$ The non linearity tested comes from the definition itself of positive and negative shocks.

${ }^{15}$ See table 3 in appendix 2.
} 


\subsubsection{Reaction function estimated by $O L S$}

Several specifications were tested. The selected specification for our reaction function is the following:

$$
\begin{gathered}
\mathrm{i}_{\mathrm{t}}=0,0194+0,6639 \mathrm{i}_{\mathrm{t}-1}+0,1926\left(\pi_{\mathrm{t}}-\pi^{*}\right)_{\mathrm{t}-1}+0,1603\left(\Delta \mathrm{m} 3_{\mathrm{t}}-\Delta \mathrm{m} 3^{*}\right)_{\mathrm{t}-1}+0,2233 \mathrm{y}_{\mathrm{t}-1}+\varepsilon_{\mathrm{t}} \\
(0,001)^{* * *}(0,000)^{* * *} \quad(0,007)^{* * *} \quad(0,003)^{* * *} \quad(0,010)^{* *}
\end{gathered}
$$

Where $\mathrm{i}$ is nominal interest rate in the short run, $\pi$ is the inflation rate, M3 is the monetary aggregate M3, $y$ is the output gap

$\overline{\mathrm{R}}^{2}=0,9519$

$\mathrm{LB}=0,1193 \quad$ White $=0,7877 \quad$ Reset $=0,2880$

Skewness $=0,50884 \quad$ Kurtosis $=1,56642$

$* *, * * *$ rejection of Ho (null coefficient) at the $5 \%$ and $1 \%$ levels respectively. P-values are written between brackets. In the same way, the indicated statistics concerning the tests of Ljung Box, White and Reset are the pvalues.

From this reaction function, we notice a very good regression quality. According to the adjusted-R ${ }^{2}, 95,2 \%$ of interest rate level at time $t$ are explained by the explanatory variables, i.e. the interest rate, the inflation gap, the growth gap of M3 and the output gap, for the previous quarter ${ }^{16}$.

The statistically significant coefficient at the 0,01 level of confidence associated with the lagged interest rate shows the concern of the ECB in smoothing the interest rate level over time. Monetary policy changes rather slowly if one refers to the weight of 0,66 . For an objective of inflation, of monetary growth and of real production reached, the level of the rate at time $t$ is about $0,66 \%$ the rate in $t-1$ and one intercept.

The weight of the inflation gap is statistically significant and positive at 0,01 level, which is in concordance with our expectations. Facing a positive gap of $1 \%$ of inflation rate compared to its objective in t-1, the ECB must increase short rate by $0,19 \%$ at time t: the short term elasticity of interest rate compared to inflation gap is 0,19 . That clearly shows the ECB's determination to keep the inflation rate with a level close to $2 \%$. When the inflation

\footnotetext{
${ }^{16}$ Moreover, this specification strictly respects non autocorrelation, homoscedasticity as well as the normality of the residuals. The implemented error specification test (reset test) indicates that all occurs as if the reaction function is well specified.
} 
quickens, the inter bank market rate must increase to reduce money supply and thus lower investment, output, employment and inflation.

As for M3 growth target, the associated coefficient is also significant at 0,01 level, which is not surprising. Indeed, it is clear that the ECB advocates a policy close to German Central bank, which for a long time assigned a growth target for money supply. In the same way, France has clearly announced a monetary growth target since 1977. Facing an M3 growth gap of $1 \%$, the ECB is likely to increase the Union short rate about $0,16 \%$ to bring back evolution of the aggregate towards target value and thus to peg the economy. This result needs nevertheless to be moderate as we underlined previously because the ECB is not compelled to react systematically to a money growth gap but supervises its evolution. Besides, the estimated coefficient is slightly lower than that of inflation gap what reinforces the idea the ECB has above all an inflation objective.

Finally, the coefficient of the output gap is statistically significant at 0,05 level. If real production exceeds its potential output of $1 \%$, ECB increases short interest rate by about $0,22 \%$. When real economic activity slows down, interest rate must decrease to raise money supply and thus to stimulate investment, production and to reduce unemployment. If we compare weights of inflation and output gaps, the latter is slightly higher. Nevertheless we must be cautious because we simulate an EMU with eight countries on the latest data which cover changes of the 80s and 90s. Moreover, we tried to test an alternative reaction function in which we omit the M3 growth. We then note that output gap is no longer significant whereas inflation gap is at the 0,01 level. This shows in conclusion that first the M3 growth gap is not neutral and then the significativity of output gap seems to be weak what strengthens once again the idea that it is in fact inflation gap which is the ultimate objective of ECB.

\subsubsection{Effects on activity in European economies}

Results obtained by $\mathrm{OLS}^{17}$ according to the selected specification and countries are reported in tables 4 to 7 in appendix 3. In each one of these charts, we present, for each selected country, coefficients of one period lagged dependant variable like those of monetary unanticipated (shock) and anticipated components (amc) up to four lag length. The choice of lag length has been carried out according to usual criteria, i.e. Akaike and Ljung Box. The addition of current value has been tested but it does not affect the results and this added coefficient is not

\footnotetext{
${ }^{17}$ The quantified results of the estimates by NLGLS for the two specifications taking account the distinction between positive and negative shocks are not reproduced because they would weigh down the already dense content of this paper.
} 
significant. We also report estimated standard deviation, adjusted- $\mathrm{R}^{2}$ as well as Ljung Box statistic. Results are also summarized for alternative estimates in tables 8 to 12 .

First of all let us analyse cases where we have imposed the symmetry of shocks and/or of anticipated part (results of specifications (3) and (4) reported in tables 4 and $5+$ syntheses in tables 8 to 10).

In table 4, the sum of coefficients corresponding to unanticipated part of interest rate is significant in seven countries out of eight. Moreover, in France, Germany, Spain, in the Netherlands and in Finland, this sum is negative as was expected. Thus, a fall in interest rate results in a relaxation in monetary conditions and an expansion in economic activity. Table 4 suggests that the assumption of nullity of effects of unanticipated monetary policy in all countries should be statistically rejected. According to these first results, it takes on average two quarters for single monetary policy to affect activity in France, Germany and Spain. The response time is shorter in Austria (one quarter) and longer in the Netherlands, Belgium and Finland (three quarters) as well as in Italy (four quarters). We note in this first stage symmetry in the direction of reactions: we cannot reject the assumption that unanticipated monetary policy has real effects on the activity in European countries.

The addition of systematic part (table 5) does not much modify these results. The sum of coefficients of the unanticipated part is significant in all countries except Italy and is moreover negative in France, Spain, in the Netherlands and in Finland. The examination of table leads us to the rejection of the nullity of unanticipated component in all countries except the Netherlands. The null assumptions associated with anticipated component are quasi systematically not rejected by data. We note that on average two quarters are necessary for unanticipated single monetary policy to affect real activity in France and Spain. The response time is shorter in Germany and Austria (one quarter) and longer in Belgium (three quarters). On the whole, these results suggest symmetry in reactions of countries to the anticipated monetary shocks, anticipated part does not have any or very few real effects. On the other hand, unanticipated shocks again appear to be very significant. We can finally note an asymmetry of answers of European economies as for the comparison of effects of anticipated and unanticipated shocks. 
In a second stage, we slacken the constraint of symmetry between positive and negative shocks in order to answer to the initial question more precisely. For that, we refer to tables 6 and 7 and to syntheses in tables 9 to 12 .

Into table 6, we introduce an asymmetry on the level of unanticipated monetary shocks: we break up them into positive/negative unanticipated monetary shocks. If we compare these results with those in table 4 where we have imposed symmetry, we note that discrimination between unanticipated shocks in positive/negative shocks reduces the relevance of results. The effects, which initially seemed rather similar about unanticipated shocks, appear different now. Indeed, reactions of the production of countries to a positive or negative unanticipated shock vary according to economies. Positive unanticipated shocks affect real activity at the end of two quarters in Germany, Spain, the Netherlands, at the end of one quarter in Austria and three quarters in Finland. The impact on real activity of the Netherlands is extended in the third quarter. Negative unanticipated shocks affect real activity at the end of one quarter in France and Germany, at the end of three quarters in the Netherlands and four quarters in Italy and Finland. We can deduce a relative asymmetry according to results of the equality test of positive/negative shocks effects.

The estimate of the system by NLGLS allows us to refine results considerably. The effects of unanticipated shocks seem overall more significant. Unanticipated interest rate rises seem to have significant effects in France, Germany, Spain, Austria and in a less clear way in the Netherlands and in Finland. As for negative shocks, they influence real activity of France, Belgium, and Finland and in a less obvious way of Spain, Italy and the Netherlands. With the exception of Italy and Belgium, we can check in all countries the non-equality of the effects of positive/negative shocks in short or long terms.

In table 7, we add a final distinction: anticipated component is in its turn broken up into anticipated positive/negative shocks as the unanticipated part. We can initially notice that anticipated positive and negative parts could be assumed to be insignificant in all countries. Positive unanticipated monetary shocks also seem more significant than negative in spite of the fact that the test of equality between these two types of shocks is rejected only in Germany, Finland and in the Netherlands. Let us note however that p-values are rather weak for several countries. On the whole, these last results show a greater sensitivity in France, Germany, Spain, in the Netherlands and Finland to the unanticipated increases in interest rate compared to unanticipated falls. A contrario, Italy and Belgium seem more sensitive to unanticipated falls. 
The valuation by NLGLS again confirms the noticed asymmetry between the effects of restrictive and expansionist unanticipated shocks. According to results, France, Germany, Spain, Finland and Austria seem more sensitive to unanticipated rises of interest rates whereas Italy, the Netherlands and Belgium would appear to be more sensitive with respect to unanticipated falls. Anticipated component always appears less significant but the difference is less noticeable. Nevertheless, the test of equality of the effects between anticipated and unanticipated monetary policy, positive then negative, suggests again that the two components have different effects.

From our results, we draw the following implications for ECB behaviour.

\subsubsection{Implications for the ECB monetary policy}

These asymmetries raised in EMU are worrying in the absence of the ability to alter exchange rates to absorb these shocks. Indeed, under single monetary policy, any interest rate change implemented by the ECB is common to all countries participating to this monetary union. Nevertheless, our results prove that these common shocks may have asymmetric real effects from one country to another. In other words, whereas EMU should a priori contribute to homogeneous monetary policy effects, differences remain. Therefore ECB monetary policy decision can not produce expected effects on whole countries and unwanted distortions may follow. The underscoring of such asymmetric effects is particularly appealing within the context of single monetary policy consequences. Besides no credible mechanism exists to combat asymmetric shocks ; the EMU does not constitute an optimum currency area.

If national economies reactions to a same interest rate change are too different, single monetary policy can produce divergences across countries. This policy could indeed generate differentiated management of shocks hitting some countries. By instance, if some countries are insensible to rate decreases whereas others answer strongly to it, an expansionist monetary policy seems to be the appropriate mean to control restrictive shocks only in the last group of countries. In other words a common monetary policy could favour to some countries in comparison with others. By another way if European economies are more sensible to positive interest rate increase, any restrictive policy, even though it is followed by expansionist monetary policy of the same size, could lead to permanent unemployment increase and permanent output fall. A monetary tightening by the ECB will produce an uneven distribution of output losses across the monetary union. This issue is especially important for ECB that has an inflation objective. Indeed, to achieve this inflation target, it can itself induce to slacken output. If inflationoutput trade off is not homogeneous within monetary union, this restrictive policy could be more costly for some countries than others. 
These asymmetries are due to structural national divergences that still exist. Cross-country differences in financial structure (credit maturity, fixed or variable interest rate, adjustability of interest rates in the mortgage market...) and in labour market disparities (wages rigidities, labour immobility, and wage bargaining...) should presumably provide explanations for the observed differences in the transmission of monetary policy. I think it could be appealing to deepen these points in further research.

With regard to the ECB policy question, these national structural differences could bring few views on the best mean to conduct single monetary policy. The question for ECB is whether it is able to take into account these structural factors in conducting single monetary policy. One way could be to introduce these national differences in ECB reaction function by way of second pillar of its strategy. These factors would be then integrated in information that it examines to take its decisions. Nonetheless, we already know the difficulty to estimate such a reaction function. On the other hand, EMU constitutes itself a profound change that will narrow over time the differences. The introduction of the Euro will first intensify banking establishment competition, and then labour markets functioning harmonisation will be initiated as part of OECD strategy employment. In that way, it could help to decrease asymmetric effects. Unfortunately, this move is not easy and will take too much time. In addition to these difficulties, cultural and traditional characteristics can prevent to lower these disparities.

\section{CONCLUSION}

The effects of monetary policy on activity have been discussed in previous literature. However, this study focuses more specifically on a European framework and more precisely within a single monetary policy framework. Indeed, few economists have studied to date the effects of this common monetary policy conducted by the European Central Bank on European countries activity introducing at the same time anticipated and unanticipated monetary policy and distinction between some expansionist or restrictive monetary policy. We should not lose sight that our objective in this article is to compare reactions of European countries to a common interest rate change.

In order to answer this question, we choose two stages estimation method as suggested by Cover (1992). We estimate a reaction function supposed to represent the behaviour of the ECB by OLS which shows clearly that the latter modifies its interest rate according to the state of economy represented by the interest rate, the inflation gap, the M3 growth gap and the output gap. From this estimate, we can easily obtain the estimated part of interest rate 
(possibly positive and negative) as well as the residual part (positive and negative) that we introduce in output equations for each European country. The estimate by OLS of output process allows us to quantify effects of this single monetary policy on real activity of these countries. We supplement the analysis by a non-linear joint estimation system to compare results and to complete conclusions.

We can ultimately conclude that the directions of reactions of European countries are similar if one is interested in effects of anticipated and unanticipated components: real production of countries reacts more to unanticipated interest rate changes.

Nevertheless, the answers of economies seem different if one is interested in asymmetry between positive and negative monetary shocks. We can highlight two sub-groups of countries. On the one hand, France, Germany, Spain and Austria seem more sensitive to unanticipated rises of interest rate i.e. to a restrictive monetary policy. On the other hand, real activity of Belgium and Italy seems to react more to an expansionist monetary policy. The Netherlands and Finland are more difficult to classify since the results of the two estimates do not coincide. With OLS, Finnish real activity seems to answer unanticipated impulses, both positive and negative according to the specification, while in the Netherlands activity reacts more to unanticipated rates rises. With the non-linear estimate, Finland seems more sensitive to negative unanticipated shocks whereas the reaction becomes mitigated in the Netherlands. These conclusions must thus be taken with cautious since results can vary according to specification of the selected production equation and the estimation.

The asymmetry of the effects of monetary shocks is finally relatively homogeneous within our Union with eight countries since all countries react little to anticipated component. The one of the effects of positive or negative shocks is less in the sense that countries react differently. Thus the single monetary policy seems to affect real variables and, consequently, the assumption of neutrality of money in long-term is perhaps not valid. If there were no really homogeneity in reactions of European economies, this single monetary policy could cause an uneven distribution of output across the monetary union and then this would raise some questions as to the best way of conducting monetary policy. The results confirm the idea that nominal convergence has not been necessarily accompanied by a real convergence. They illustrate all the problems of single monetary policy: a common change of monetary policy in all countries can lead to asymmetric reactions because these countries still have different national structures. 


\section{REFERENCES}

Bernanke, B.S. and Mihov I. (1995) Measuring monetary policy. Quarterly Journal of Economics 113 (3):869-902.

Bordes, C. (1997) La politique monétaire. In Politiques économiques (G. Duthil and W. Marois, eds.). Ellipses.

Clarida, R., Gali, J. and Gertler, M. (1998) Monetary policy rules in practice: some international evidence. European Economic Review 42: 1033-1067.

Cochrane, J. H. (1995) Identifying the output effects of monetary policy. NBER Working Paper, No 5154.

Cover, J.P. (1992) Asymmetric effects of positive and negative money-supply shocks. The Quarterly Journal of Economics 107: 1261-1282.

De Long, B.J. and Summers, L.H. (1988) How does macroeconomic policy affect output? Brookings Papers on Economic Activity 2: 433-480.

Dornbusch, R., Favero, C. and Giavazzi, F. (1998) Immediate challenges for the European Central Bank. Economic Policy 26: 15-52.

European Central Bank, (2001) The monetary policy of the ECB. Francfort.

Garcia, R. and Schaller H. (1995) Are the effects of monetary policy asymmetric? University of Montreal Working Paper No 0595.

Gerlach, S. and Schnabel, G. (1999) The Taylor rule and interest rates in the EMU area: a note. Bank for International Settlements Working Paper No 73.

Jaillet, P. (1998) Stratégies de politique monétaire: quelques enseignements du passé récent et pistes pour l'avenir. Revue économique: 629-641.

Kahn, G.A. (1988) Nominal GDP: an anchor for monetary policy. Economic Review, Federal Reserve Bank of Kansas City 18-35.

Karras, G. (1996) Are the output effects on monetary policy asymmetric? Evidence from a sample of European countries. Oxford Bulletin of Economics and Statistics 58 (2): 267-277.

Lucas, R.E. (1973) Some international evidence on output-inflation trade-offs. American Economic Review 63: 326-334.

McCallum, B.T. (1987) The case for rules in the conduct of monetary policy: a concrete example. Economic Review, Federal Reserve Bank of Richmond: 10-18. 
McCallum, B.T. (1988) Robustness properties of a rule for monetary policy. Carnegie-Rochester Conference Series on Public Policy 29: 173-203.

McCallum, B.T. (1993) Discretion versus policy rules in practice: two critical points - A comment. Rochester Conference Series on Public Policy 39.

McCallum, B.T. (1995) Rules for monetary policy. NBER Reporter: 5-8.

Mishkin, F.S. (1982) Does anticipated monetary policy matter? An econometric investigation. Journal of Political Economy 90 (1): 22-51.

Romer, C. D. and Romer, D.H. (1989) Does monetary policy matter? A new test in the spirit of Friedman and Schwartz. NBER Macroeconomic Annual 1989, Cambridge, MIT Press: 121-170.

Tavéra, C., Cadoret, I. and Payelle, N. (1998) La convergence des asymétries dans les effets réels des impulsions monétaires. In La convergence des économies européennes (C. Tavéra, Ed.), Economica : 121-137.

Taylor, J.B. (1993) Discretion versus policy rules in practice. Carnegie-Rochester Conference Series on Public Policy 39: 195-214.

Verdelhan, A. (1999) Règle de Taylor. Report of the Bank of France 96:85-9. 


\section{Appendix 1: Presentation of data and unit root tests}

\subsection{Presentation of data}

To complete this work, we collected data of nominal short-term interest rate of money market in \% (line 60b) in the "International Financial Statistical" database of the International Monetary Fund. Data of real Gross Domestic Product in billion Euro were extracted from Eurostat database. Series of Consumer Price Index all products confused base 100 in 1995 come from the OECD. Series of monetary aggregate M3 result either from the OECD, or from the IMF (IFS) or from the National Bank of Belgium for Belgium and from the Bank of Italy for Italy: they are either in billion Euro or in billion national currency units. These data are transformed into logarithms except for interest rate.

In addition we supposed that only eight countries belong to the Euro zone because of problems of availability of data. However, the sum of GDP of these eight countries represents approximately $98 \%$ of total GDP of the Union this is why this assumption does not seem to us at all restrictive. Quarterly and seasonally adjusted data are available over the period 1980/1998.

\subsection{Results of unit root tests}

Augmented unit root tests by Dickey-Fuller were carried out on our series in order to deduce the adequate integration order. We also sought the presence of a deterministic trend using the test of Stock and Watson that we apply to series made stationary. Lastly, we applied the test of Perron to check the existence or not of a temporary break. The obtained results are summarized below:

Table 1 : Dickey-Fuller tests

\begin{tabular}{|c|c|}
\hline Series & Conclusions \\
\hline Aggregate Interest rate $\left(\mathrm{i}^{\mathrm{A}}\right)$ & $\mathrm{I}(1)$ with break in 1988:3 \\
Aggregate Inflation rate $\left(\pi^{\mathrm{A}}\right)$ & $\mathrm{I}(1)$ \\
Aggregate Monetary aggregate $\mathrm{M} 3\left(\mathrm{M}^{\mathrm{A}}\right)$ & $\mathrm{I}(1)$ \\
Output gap of the Union $\left(\mathrm{y}^{\mathrm{A}}\right)$ & $\mathrm{I}(0)$ \\
GDP of each country & $\mathrm{I}(1)$ \\
\hline
\end{tabular}

Table 2 : Dummies

\begin{tabular}{|l|l|}
\hline France & $\begin{array}{l}\text { Competitive disinflation in 83; financial market evolutions and realignment in 86; } \\
\text { deregulation of prices in 87;German reunification in 90/91; recession in 92/93; crisis in 95. }\end{array}$ \\
\hline Germany & Lower production in 81/82; reunification in 90/91; recession in 92/93. \\
\hline Spain & Lower interest rate in 86; German reunification in 90/91; recession in 92/93. \\
\hline Italy & Recession in 92/93; crisis in 95; lower GDP in 82 \\
\hline Netherlands & Lower GDP in 82; financial market trend in 85; German reunification in 90; crisis of 92/93. \\
\hline Belgium & German reunification in 90/91; recession at the beginning of 92; exchange rate crisis in 93. \\
\hline Finland & Inflation acceleration in 85; recession from 90 to 94. \\
\hline Austria & German reunification in 90; lower economy in 92. \\
\hline
\end{tabular}


Table 3 : Tests

\begin{tabular}{|c|c|}
\hline \multirow{2}{*}{$\begin{array}{ll} & \text { Null hypothesis tested } \\
\text { Table1: } & \end{array}$} & Notation \\
\hline & \\
\hline Nullity of the effects of unanticipated monetary policy & shock $=0$ \\
\hline Neutrality of the effects of unanticipated monetary policy & $\sum$ shock $=0$ \\
\hline \multicolumn{2}{|l|}{ Table 2: } \\
\hline Nullity of the effects of unanticipated monetary policy & shock $=0$ \\
\hline Neutrality of the effects of unanticipated monetary policy & $\Sigma$ shock $=0$ \\
\hline Nullity of the effects of anticipated monetary policy & $\mathrm{amc}=0$ \\
\hline Neutrality of the effects of anticipated monetary policy & $\Sigma \mathrm{amc}=0$ \\
\hline Equality of the effects of unanticipated and anticipated components & shock $=$ amc \\
\hline $\begin{array}{l}\text { Equality of the total multiplier effects of unanticipated and anticipated } \\
\text { components }\end{array}$ & $\Sigma$ shock $=\Sigma$ amc \\
\hline \multicolumn{2}{|l|}{ Table 3: } \\
\hline Nullity of the effects of positive unanticipated monetary policy & $\operatorname{shock}^{+}=0$ \\
\hline Neutrality of the effects of positive unanticipated monetary policy & $\sum \operatorname{shock}^{+}=0$ \\
\hline Nullity of the effects of negative unanticipated monetary policy & shock $^{-}=0$ \\
\hline Neutrality of the effects of negative unanticipated monetary policy & $\Sigma$ shock $^{-}=0$ \\
\hline $\begin{array}{l}\text { Equality of the effects of positive and negative unanticipated monetary } \\
\text { policy }\end{array}$ & shock $^{+}=$shock $^{-}$ \\
\hline $\begin{array}{l}\text { Equality of the total multiplier effects of unanticipated positive and negative } \\
\text { monetary policy }\end{array}$ & $\sum \operatorname{shock}^{+}=\sum$ shock $^{-}$ \\
\hline \multicolumn{2}{|l|}{ Table 4: } \\
\hline Nullity of the effects of positive unanticipated monetary policy & $\operatorname{shock}^{+}=0$ \\
\hline Neutrality of the effects of positive unanticipated monetary policy & $\sum$ shock $^{+}=0$ \\
\hline Nullity of the effects of negative unanticipated monetary policy & shock $^{-}=0$ \\
\hline Neutrality of the effects of negative unanticipated monetary policy & $\Sigma$ shock $^{-}=0$ \\
\hline $\begin{array}{l}\text { Equality of the effects of positive and negative unanticipated monetary } \\
\text { policy }\end{array}$ & $\operatorname{shock}^{+}=$shock $^{-}$ \\
\hline $\begin{array}{l}\text { Equality of the total multiplier effects of positive and negative unanticipated } \\
\text { monetary policy }\end{array}$ & $\Sigma$ shock $^{+}=\Sigma$ shock $^{-}$ \\
\hline Nullity of the effects of positive anticipated monetary policy & $\mathrm{amc}^{+}=0$ \\
\hline Neutrality of the effects of positive anticipated monetary policy & $\Sigma \mathrm{amc}^{+}=0$ \\
\hline Nullity of the effects of negative anticipated monetary policy & $\mathrm{amc}^{-}=0$ \\
\hline Neutrality of the effects of negative anticipated monetary policy & $\Sigma \mathrm{amc}^{-}=0$ \\
\hline $\begin{array}{l}\text { Equality of the effects of positive and negative anticipated monetary policy } \\
\text { monetarist }\end{array}$ & $\mathrm{amc}^{+}=\mathrm{amc}^{-}$ \\
\hline $\begin{array}{l}\text { Equality of the total multiplier effects of positive and negative anticipated } \\
\text { monetary policy }\end{array}$ & $\Sigma \mathrm{amc}^{+}=\Sigma \mathrm{amc}^{-}$ \\
\hline $\begin{array}{l}\text { Equality of the effects positive anticipated and unanticipated of monetary } \\
\text { policy }\end{array}$ & $\operatorname{shock}^{+}=\mathrm{amc}^{+}$ \\
\hline $\begin{array}{l}\text { Equality of the total multiplier effects of positive anticipated and } \\
\text { unanticipated monetary policy }\end{array}$ & $\sum \operatorname{shock}^{+}=\sum \mathrm{amc}^{+}$ \\
\hline $\begin{array}{l}\text { Equality of the effects of negative anticipated and unanticipated monetary } \\
\text { policy }\end{array}$ & shock $^{-}=\mathrm{amc}^{-}$ \\
\hline $\begin{array}{l}\text { Equality of the total multiplier effects of negative anticipated and } \\
\text { unanticipated monetary policy }\end{array}$ & $\Sigma$ shock $^{-}$ \\
\hline $\begin{array}{l}\text { Equality of the effects of positive and negative anticipated and } \\
\text { unanticipated monetary policy }\end{array}$ & $\operatorname{shock}^{+}=\operatorname{shock}^{-}=\mathrm{amc}^{+}=\mathrm{amc}^{-}$ \\
\hline $\begin{array}{l}\text { Equality of the total multiplier effects of negative and positive anticipated } \\
\text { and unanticipated monetary policy }\end{array}$ & $\begin{array}{c}\sum \operatorname{shock}^{+}=\sum \text { shock }^{-}= \\
\sum \mathrm{amc}^{+}=\sum \mathrm{amc}^{-}\end{array}$ \\
\hline
\end{tabular}


Appendix 3: Measures of effects of single monetary shocks on countries' activity

Table 4: Effects of unanticipated monetary policy on the activity

\begin{tabular}{|c|c|c|c|c|c|c|c|c|}
\hline & \multicolumn{2}{|c|}{ France } & \multicolumn{2}{|c|}{ Germany } & \multicolumn{2}{|c|}{ Spain } & \multicolumn{2}{|c|}{ Italy } \\
\hline & Coef. & p-value & Coef. & p-value & Coef. & p-value & Coef. & p-value \\
\hline$\Delta \mathbf{y}_{\mathrm{t}-1}$ & 0,0552 & 0,6352 & $-0,1517$ & 0,2179 & 0,3383 & $0,0070 * * *$ & $-0,0313$ & 0,7921 \\
\hline shock $_{t-1}$ & 0,0136 & 0,9171 & 0,2453 & 0,3437 & 0,0125 & 0,7894 & 0,1578 & 0,2096 \\
\hline shock $_{\mathrm{t}-2}$ & $-0,2297$ & $0,0838 *$ & $-0,6876$ & $0,0105^{* *}$ & $-0,1055$ & $0,0340 * *$ & 0,0400 & 0,7571 \\
\hline shock $_{t-3}$ & $-0,1345$ & 0,3011 & $-0,1571$ & 0,5633 & $-0,1212$ & $0,0105^{* *}$ & 0,0158 & 0,8972 \\
\hline shock $_{t-4}$ & $-0,0641$ & 0,5414 & $-0,1861$ & 0,3704 & $-0,0398$ & 0,3143 & $-0,3113$ & $0,0017 * * *$ \\
\hline shock $=0$ & & 0,2392 & & $0,0724 *$ & & $0,0463 * *$ & & $0,0209 * *$ \\
\hline इshock $=0$ & $-0,4149$ & $0,0570 *$ & $-0,7855$ & $0,0770^{*}$ & $-0,2540$ & $0,0545^{*}$ & $-0,0976$ & 0,6134 \\
\hline$\sigma$ & & 0,0051 & & 0,0102 & & 0,0018 & & 0,0048 \\
\hline$\overline{\mathbf{R}}^{2}$ & & 0,2296 & & 0,3251 & & 0,8352 & & 0,3147 \\
\hline LB & 18,183 & 0,3132 & 13,257 & 0,6538 & 22,875 & 0,0868 & 10,566 & 0,8354 \\
\hline
\end{tabular}

\begin{tabular}{|c|c|c|c|c|c|c|c|c|}
\hline & \multicolumn{2}{|c|}{ Netherlands } & \multicolumn{2}{c|}{ Belgium } & \multicolumn{2}{c|}{ Finland } & \multicolumn{2}{c|}{ Austria } \\
\cline { 2 - 9 } & Coef. & p-value & Coef. & p-value & Coef. & p-value & Coef. & p-value \\
\hline$\Delta \mathbf{y}_{\mathbf{t}-1}$ & $-0,3400$ & $0,0031^{* * *}$ & $-0,1243$ & 0,2935 & $-0,0125$ & 0,9203 & $-0,1242$ & 0,3120 \\
shock $_{\mathbf{t}-\mathbf{1}}$ & $-0,0616$ & 0,7266 & 0,1874 & 0,2355 & 0,0556 & 0,8407 & 1,9971 & $0,0120^{* *}$ \\
shock $_{\mathbf{t}-\mathbf{2}}$ & $-0,1617$ & 0,3685 & 0,2266 & 0,1325 & $-0,1900$ & 0,5049 & 0,3568 & 0,6416 \\
shock $_{\mathbf{t}-\mathbf{3}}$ & $-0,3755$ & $0,0368^{* *}$ & 0,3113 & $0,0433^{* *}$ & $-0,6486$ & $0,0213^{* *}$ & $-0,1551$ & 0,8364 \\
shock $_{\mathbf{t}-\mathbf{4}}$ & $-0,2396$ & $0,0998^{*}$ & $-0,0586$ & 0,6221 & $-0,1250$ & 0,5765 & 0,3422 & 0,5626 \\
\hline \hline shock=0 & & $0,0440^{* *}$ & & $0,0384^{* *}$ & & $0,0975^{*}$ & & $0,0851^{*}$ \\
$\mathbf{\Sigma}$ shock=0 $^{*}-0,8386$ & $0,0065^{* * *}$ & 0,6667 & $0,0105^{* *}$ & $-0,9080$ & $0,0404^{* *}$ & 2,8513 & $0,0225^{* *}$ \\
$\boldsymbol{\sigma}$ & & 0,0069 & & 0,0059 & & 0,0109 & & 0,0294 \\
$\overline{\mathbf{R}}^{2}$ & & 0,3252 & & 0,4893 & & 0,3584 & & 0,1830 \\
$\mathbf{L B}$ & 24,961 & 0,0705 & 21,983 & 0,1437 & 13,463 & 0,6385 & 4,5316 & 0,9976 \\
\hline
\end{tabular}

$*, * *, * * *$ rejection of the null hypothesis at $10 \%, 5 \%$ and $1 \%$ level respectively,

LB: Ljung-Box statistic

Equation (3) estimated for each country:

$\Delta \mathrm{y}_{\mathrm{t}}=$ constant $+\mathrm{a} \Delta \mathrm{y}_{\mathrm{t}-1}+\sum_{\mathrm{m}=1}^{4} \mathrm{~b}_{\mathrm{m}} \varepsilon_{\mathrm{t}-\mathrm{m}}+\mathrm{v}_{1 \mathrm{t}}$

Where $\varepsilon$ is equivalent to the series shock in the table, $\mathrm{y}$ is real GDP of the country 
Table 5: Effects of anticipated and unanticipated monetary policy on the activity

\begin{tabular}{|c|c|c|c|c|c|c|c|c|}
\hline & \multicolumn{2}{|c|}{ France } & \multicolumn{2}{|c|}{ Germany } & \multicolumn{2}{|c|}{ Spain } & \multicolumn{2}{|c|}{ Italy } \\
\hline & Coef. & p-value & Coef. & p-value & Coef. & p-value & Coef. & p-value \\
\hline$\Delta \mathbf{y}_{\mathrm{t}-1}$ & 0,0493 & 0,6658 & $-0,0858$ & 0,5260 & 0,8556 & $0,0000 * * *$ & 0,0008 & 0,9949 \\
\hline $\operatorname{shock}_{t-1}$ & $-0,0672$ & 0,6181 & 0,5338 & $0,0768 *$ & $-0,0099$ & 0,8401 & 0,1759 & 0,2334 \\
\hline $\operatorname{shock}_{t-2}$ & $-0,3554$ & $0,0377 * *$ & $-0,2480$ & 0,5547 & $-0,1805$ & $0,0203 * *$ & 0,1854 & 0,4407 \\
\hline $\operatorname{shock}_{t-3}$ & 0,1620 & 0,5051 & $-0,5055$ & 0,4833 & 0,0887 & 0,4553 & $-0,1124$ & 0,7514 \\
\hline $\operatorname{shock}_{t-4}$ & $-0,3396$ & 0,1136 & 1,1676 & $0,0433 * *$ & $-0,0487$ & 0,5875 & $-0,3897$ & 0,1519 \\
\hline$a m c_{t-1}$ & 0,1660 & 0,1310 & $-0,1781$ & 0,5636 & 0,1025 & $0,0811 *$ & $-0,0705$ & 0,6849 \\
\hline $\mathrm{amc}_{\mathrm{t}-2}$ & 0,1535 & 0,1619 & 0,2234 & 0,3909 & 0,0848 & 0,1738 & $-0,0839$ & 0,6567 \\
\hline $\mathbf{a m c}_{\mathrm{t}-3}$ & 0,2094 & $0,0417 * *$ & 0,1531 & 0,5075 & 0,0217 & 0,6684 & $-0,1211$ & 0,4285 \\
\hline $\mathrm{amc}_{\mathrm{t}-4}$ & 0,1390 & $0,0350 * *$ & 0,0479 & 0,7430 & $-0,0325$ & 0,2268 & $-0,0476$ & 0,5478 \\
\hline shock $=0$ & & $0,0794^{*}$ & & $0,0246 * *$ & & $0,0482 * *$ & & $0,0896^{*}$ \\
\hline $\begin{array}{c}\Sigma \text { shock }=0 \\
\text { amc }=0\end{array}$ & $-0,6003$ & $\begin{array}{c}0,0088 * * * \\
0,1405\end{array}$ & 0,9477 & $\begin{array}{c}0,0511^{*} \\
0,4184\end{array}$ & $-0,1505$ & $\begin{array}{l}0,0627^{*} \\
0,0755^{*}\end{array}$ & $-0,1407$ & $\begin{array}{l}0,5433 \\
0,7930\end{array}$ \\
\hline Samc=0 & 0,6681 & $0,0352 * *$ & 0,2463 & 0,7423 & 0,1766 & 0,3065 & $-0,3234$ & 0,5345 \\
\hline shock=amc & & $0,0281 * *$ & & $0,0310 * *$ & & 0,1688 & & 0,1243 \\
\hline$\Sigma$ shock $=\Sigma$ amc & & $0,0028 * * *$ & & 0,4541 & & $0,0700 *$ & & 0,7320 \\
\hline$\sigma$ estimated & & 0,0050 & & 0,0112 & & 0,0017 & & 0,0050 \\
\hline$\overline{\mathbf{R}}^{2}$ & & 0,2778 & & 0,1895 & & 0,8597 & & 0,2348 \\
\hline LB & 8,8862 & 0,9180 & 11,064 & 0,8054 & 27,505 & 0,0248 & 11,430 & 0,7215 \\
\hline
\end{tabular}

\begin{tabular}{|c|c|c|c|c|c|c|c|c|}
\hline & \multicolumn{2}{|c|}{ Netherlands } & \multicolumn{2}{|c|}{ Belgium } & \multicolumn{2}{|c|}{ Finland } & \multicolumn{2}{|c|}{ Austria } \\
\hline & Coef. & p-value & Coef. & p-value & Coef. & p-value & Coef. & p-value \\
\hline$\Delta \mathbf{y}_{\mathrm{t}-1}$ & $-0,2268$ & $0,0672 *$ & $-0,1427$ & 0,2529 & 0,0180 & 0,8904 & $-0,1267$ & 0,3364 \\
\hline shock $_{t-1}$ & $-0,0257$ & 0,8879 & 0,2517 & 0,1727 & 0,0323 & 0,9181 & 2,6711 & $0,0056^{* * *}$ \\
\hline shock $_{t-2}$ & 0,0436 & 0,8777 & $-0,0947$ & 0,7172 & 0,1135 & 0,8231 & $-0,6256$ & 0,6508 \\
\hline shock $_{t-3}$ & $-0,2872$ & 0,5084 & 1,0659 & $0,0118 * *$ & $-1,2391$ & 0,1180 & 0,9395 & 0,6571 \\
\hline $\operatorname{shock}_{t-4}$ & $-0,3381$ & 0,3083 & $-0,5922$ & $0,0600 *$ & 0,0116 & 0,9838 & 0,9161 & 0,5796 \\
\hline $\mathbf{a m c}_{\mathrm{t}-1}$ & $-0,1163$ & 0,5840 & 0,2262 & 0,2586 & $-0,4449$ & 0,2388 & 0,8820 & 0,3984 \\
\hline $\mathbf{a m c}_{\mathrm{t}-2}$ & $-0,3299$ & 0,1450 & $-0,0938$ & 0,6598 & $-0,4569$ & 0,2455 & 1,1669 & 0,3023 \\
\hline $\mathbf{a m c}_{\mathrm{t}-3}$ & $-0,3745$ & $0,0411 * *$ & $-0,2710$ & 0,1216 & $-0,4063$ & 0,2034 & 0,7418 & 0,4191 \\
\hline $\mathrm{amc}_{\mathrm{t}-4}$ & $-0,1703$ & $0,0744^{*}$ & $-0,1526$ & $0,0973^{*}$ & $-0,1028$ & 0,5429 & 0,0896 & 0,8518 \\
\hline shock $=0$ & & 0,2227 & & $0,0080 * * *$ & & $0,0591 *$ & & $0,0429 * *$ \\
\hline इshock=0 & $-0,6075$ & $0,0639^{*}$ & 0,6307 & $0,0385 * *$ & $-1,0816$ & $0,0328 * *$ & 3,9013 & $0,0120^{* *}$ \\
\hline amc $=0$ & & 0,2747 & & $0,0918 *$ & & 0,5166 & & 0,8195 \\
\hline$\Sigma$ amc=0 & $-0,9913$ & 0,1138 & $-0,2912$ & 0,6213 & $-1,4109$ & 0,1988 & 2,8804 & 0,3563 \\
\hline shock=amc & & 0,7629 & & $0,0174 * *$ & & 0,5953 & & 0,2011 \\
\hline$\Sigma$ shock $=\Sigma$ amc & & 0,5487 & & 0,1359 & & 0,7681 & & 0,7436 \\
\hline$\sigma$ estimated & & 0,0061 & & 0,0059 & & 0,0109 & & 0,0306 \\
\hline$\overline{\mathrm{R}}^{2}$ & & 0,2569 & & 0,5118 & & 0,3749 & & 0,1654 \\
\hline LB & 14,148 & 0,5143 & 21,757 & 0,1143 & 11,879 & 0,6880 & 5,1913 & 0,9903 \\
\hline
\end{tabular}

$*, * *, * * *$ : rejection of Ho respectively at 10,5 and $1 \%$ level,

Equation (4) estimated for each country:

$\Delta \mathrm{y}_{\mathrm{t}}=$ constant $+\mathrm{a} \Delta \mathrm{y}_{\mathrm{t}-1}+\sum_{\mathrm{m}=1}^{4} \mathrm{~b}_{\mathrm{m}} \varepsilon_{\mathrm{t}-\mathrm{m}}+\sum_{\mathrm{m}=1}^{4} \mathrm{c}_{\mathrm{m}} \hat{\mathrm{i}}_{\mathrm{t}-\mathrm{m}}+\mathrm{v}_{2 \mathrm{t}}$

Where $\hat{i}$ is equal to "amc" in table i.e, anticipated monetary policy. 
Table 6 : Effects of negative / positive unanticipated monetary shocks on the activity

\begin{tabular}{|c|c|c|c|c|c|c|c|c|}
\hline & \multicolumn{2}{|c|}{ France } & \multicolumn{2}{|c|}{ Germany } & \multicolumn{2}{|c|}{ Spain } & \multicolumn{2}{|c|}{ Italy } \\
\hline & Coef. & p-value & Coef. & p-value & Coef. & p-value & Coef. & p-value \\
\hline$\Delta \mathbf{y}_{\mathrm{t}-1}$ & 0,0666 & 0,5460 & $-0,3755$ & 0,0030 *** & 0,7798 & $0,0000 * * *$ & $-0,0649$ & 0,5736 \\
\hline shock $_{t-1}^{+}$ & $-0,1414$ & 0,3200 & $-0,0608$ & 0,8149 & 0,0050 & 0,9392 & $-0,0822$ & 0,5383 \\
\hline shock $_{t-2}^{+}$ & $-0,0817$ & 0,5639 & $-0,4894$ & $0,0625^{*}$ & $-0,2388$ & $0,0004 * * *$ & $-0,0869$ & 0,5089 \\
\hline shock $_{t-3}^{+}$ & 0,0144 & 0,9211 & $-0,3089$ & 0,2492 & $-0,0316$ & 0,6308 & 0,0181 & 0,8903 \\
\hline shock $_{t-4}^{+}$ & 0,0339 & 0,8063 & $-0,2088$ & 0,4185 & 0,0683 & 0,2882 & $-0,0624$ & 0,6256 \\
\hline shock $_{t-1}^{-}$ & 0,3861 & $0,0683^{*}$ & 0,7260 & $0,0634^{*}$ & 0,1141 & 0,2461 & 0,3272 & 0,1158 \\
\hline shock $_{t-2}^{-}$ & 0,3016 & 0,1638 & 0,0344 & 0,9323 & $-0,0014$ & 0,9880 & 0,2321 & 0,2646 \\
\hline shock $_{t-3}^{-}$ & 0,0614 & 0,7727 & $-0,0153$ & 0,9682 & $-0,1405$ & 0,1510 & 0,0164 & 0,9337 \\
\hline shock $_{t-4}^{-}$ & 0,0886 & 0,6764 & 0,0385 & 0,9208 & 0,0658 & 0,5109 & $-0,6640$ & $0,0014 * * *$ \\
\hline shock $^{+}=0$ & & 0,8377 & & 0,2668 & & $0,0084 * * *$ & & 0,9060 \\
\hline$\Sigma$ shock $^{+}=0$ & $-0,1748$ & 0,5611 & $-1,0680$ & $0,0590^{*}$ & $-0,1972$ & 0,1508 & $-0,2135$ & 0,4325 \\
\hline shock $^{-}=0$ & & 0,1973 & & 0,4523 & & 0,3760 & & $0,0094 * * *$ \\
\hline$\Sigma$ shock $^{-}=0$ & 0,8378 & $0,0441 * *$ & 0,7835 & 0,3039 & 0,0378 & 0,8376 & $-0,0882$ & 0,8191 \\
\hline shock $^{+}=$shock $^{-}$ & & 0,2813 & & 0,4749 & & 0,3327 & & $0,0750 *$ \\
\hline$\Sigma$ shock $^{+}=\Sigma$ shock $^{-}$ & & $0,0960^{*}$ & & $0,0942 *$ & & 0,3908 & & 0,8228 \\
\hline$\sigma$ estimated & & 0,0050 & & 0,0091 & & 0,0023 & & 0,0046 \\
\hline$\overline{\mathbf{R}}^{2}$ & & 0,2313 & & 0,4323 & & 0,7658 & & 0,3523 \\
\hline LB & 22,019 & 0,2311 & 24,649 & 0,1348 & 22,212 & 0,2227 & 9,5956 & 0,9443 \\
\hline
\end{tabular}

\begin{tabular}{|c|c|c|c|c|c|c|c|c|}
\hline & \multicolumn{2}{|c|}{ Netherlands } & \multicolumn{2}{|c|}{ Belgium } & \multicolumn{2}{|c|}{ Finland } & \multicolumn{2}{|c|}{ Austria } \\
\hline & Coef. & p-value & Coef. & p-value & Coef. & p-value & Coef. & p-value \\
\hline$\Delta \mathbf{y}_{\mathrm{t}-1}$ & $-0,3766$ & $0,0006^{* * *}$ & 0,0039 & 0,9734 & $-0,0095$ & 0,9320 & $-0,0654$ & 0,5795 \\
\hline shock $_{t-1}^{+}$ & 0,2236 & 0,2738 & $-0,1226$ & 0,4887 & 0,3013 & 0,2991 & 1,6201 & $0,0533^{*}$ \\
\hline shock $_{t-2}^{+}$ & 0,3706 & $0,0628^{*}$ & 0,0332 & 0,8507 & $-0,3831$ & 0,1846 & 0,2990 & 0,7215 \\
\hline shock $_{t-3}^{+}$ & 0,4857 & $0,0115 * *$ & 0,1216 & 0,5003 & $-0,5106$ & $0,0849 *$ & 0,6989 & 0,4047 \\
\hline shock $_{t-4}^{+}$ & $-0,2298$ & 0,2122 & $-0,1280$ & 0,4630 & 0,3682 & 0,1972 & 0,8082 & 0,3157 \\
\hline shock $_{t-1}^{-}$ & $-0,2702$ & 0,3441 & 0,2868 & 0,2920 & $-0,4775$ & 0,2607 & 0,4106 & 0,7368 \\
\hline shock $_{t-2}^{-}$ & $-0,1196$ & 0,6808 & 0,1140 & 0,6748 & 0,5271 & 0,2265 & 0,4267 & 0,7306 \\
\hline shock $_{t-3}^{-}$ & $-0,5993$ & $0,0466^{* *}$ & 0,4268 & 0,1083 & $-0,3993$ & 0,3550 & 0,5612 & 0,6448 \\
\hline shock $_{t-4}^{-}$ & $-0,1836$ & 0,5471 & 0,1408 & 0,5967 & $-0,9520$ & $0,0316^{* *}$ & $-0,0916$ & 0,9400 \\
\hline shock $^{+}=0$ & & $0,0209 * *$ & & 0,8168 & & 0,1057 & & 0,2703 \\
\hline$\Sigma$ shock $^{+}=0$ & 0,8502 & $0,0755^{*}$ & $-0,0956$ & 0,7941 & $-0,2241$ & 0,7036 & 3,4264 & $0,0537 *$ \\
\hline shock $^{-}=0$ & & 0,3094 & & 0,3675 & & $0,0588^{*}$ & & 0,9759 \\
\hline$\Sigma$ shock $^{-}=0$ & $-1,1727$ & $0,0758^{*}$ & 0,9687 & $0,0662 *$ & $-1,3017$ & 0,1123 & 1,3069 & 0,5794 \\
\hline shock $^{+}=$shock $^{-}$ & & $0,0754^{*}$ & & 0,6187 & & $0,0443 * *$ & & 0,9228 \\
\hline$\Sigma$ shock $^{+}=\Sigma$ shock $^{-}$ & & $0,0494 * *$ & & 0,1550 & & 0,3648 & & 0,5360 \\
\hline$\sigma$ estimated & & 0,0063 & & 0,0063 & & 0,0101 & & 0,0292 \\
\hline$\overline{\mathbf{R}}^{2}$ & & 0,4761 & & 0,4273 & & 0,4124 & & 0,1424 \\
\hline LB & 16,089 & 0,5862 & 22,612 & 0,2059 & 20,154 & 0,3241 & 4,1082 & 0,9991 \\
\hline
\end{tabular}

Equation (5) estimated for each country: $\Delta \mathrm{y}_{\mathrm{t}}=$ constant $+\mathrm{a} \Delta \mathrm{y}_{\mathrm{t}-1}+\sum_{\mathrm{m}=1}^{4} \mathrm{~b}_{\mathrm{m}}^{+} \varepsilon_{\mathrm{t}-\mathrm{m}}^{+}+\sum_{\mathrm{m}=1}^{4} \mathrm{~b}_{\mathrm{t}-\mathrm{m}}^{-} \varepsilon_{\mathrm{t}-\mathrm{m}}^{-}+\mathrm{v}_{3 \mathrm{t}}$ 
Table 7 : Effects of positive/negative and unanticipated/anticipated monetary policy

\begin{tabular}{|c|c|c|c|c|c|c|c|c|}
\hline & \multicolumn{2}{|c|}{ France } & \multicolumn{2}{|c|}{ Germany } & \multicolumn{2}{|c|}{ Spain } & \multicolumn{2}{|c|}{ Italy } \\
\hline & Coef. & p-value & Coef. & p-value & Coef. & p-value & Coef. & $p$-value \\
\hline$\Delta \mathbf{y}_{\mathrm{t}-1}$ & $-0,0586$ & 0,6323 & $-0,2354$ & $0,0622 *$ & 0,8277 & $0,0000^{* * *}$ & $-0,0875$ & 0,5400 \\
\hline shock $_{t-1}^{+}$ & $-0,1257$ & 0,3755 & 0,0598 & 0,8293 & 0,0260 & 0,6961 & $-0,0752$ & 0,6095 \\
\hline shock $_{t-2}^{+}$ & $-0,3621$ & $0,0361 * *$ & $-0,5175$ & 0,1151 & $-0,3095$ & $0,0000^{* * *}$ & $-0,0296$ & 0,8422 \\
\hline shock $_{t-3}^{+}$ & $-0,0335$ & 0,8498 & $-0,3942$ & 0,2490 & 0,0034 & 0,9636 & 0,0296 & 0,8597 \\
\hline shock $_{t-4}^{+}$ & $-0,1677$ & 0,3017 & $-0,3636$ & 0,2489 & 0,0579 & 0,4275 & $-0,0017$ & 0,9913 \\
\hline shock $_{t-1}^{-}$ & 0,1872 & 0,4054 & 0,6575 & 0,1338 & 0,1235 & 0,2578 & 0,3572 & 0,1598 \\
\hline shock $_{\mathbf{t}-2}^{-}$ & $-0,1140$ & 0,6536 & 0,1423 & 0,7782 & $-0,0404$ & 0,7509 & 0,3627 & 0,2676 \\
\hline shock $_{t-3}^{-}$ & 0,4954 & 0,1286 & 0,2357 & 0,6997 & $-0,0967$ & 0,5222 & $-0,3902$ & 0,3240 \\
\hline shock $_{\mathbf{t}-4}^{-}$ & $-0,2928$ & 0,3526 & 0,8314 & 0,1754 & 0,0493 & 0,7455 & $-0,6227$ & $0,0506^{*}$ \\
\hline $\mathbf{a m c}_{\mathbf{t}-1}^{+}$ & 0,2881 & $0,0383 * *$ & 0,1137 & 0,6546 & $-0,0130$ & 0,8545 & $-0,2434$ & 0,1616 \\
\hline $\mathbf{a m c}_{\mathbf{t - 2}}^{+}$ & 0,0705 & 0,5463 & 0,0812 & 0,7173 & 0,0044 & 0,9511 & $-0,1057$ & 0,5087 \\
\hline $\mathbf{a m c}_{\mathbf{t}-3}^{+}$ & 0,2627 & $0,0230 * *$ & 0,1466 & 0,4932 & $-0,0859$ & 0,2182 & $-0,2158$ & 0,1462 \\
\hline $\mathbf{a m c}_{\mathbf{t}-4}^{+}$ & 0,1643 & $0,0822 *$ & $-0,2698$ & 0,1273 & $-0,0606$ & 0,2169 & $-0,0421$ & 0,6959 \\
\hline $\mathbf{a m c}_{\mathbf{t - 1}}^{-}$ & 0,0798 & 0,4791 & $-0,2552$ & 0,2425 & 0,1008 & $0,0715^{*}$ & $-0,0429$ & 0,7433 \\
\hline $\mathbf{a m c}_{\mathbf{t - 2}}^{-}$ & 0,2937 & $0,0449 * *$ & $-0,1713$ & 0,5424 & 0,0524 & 0,5429 & $-0,2432$ & 0,2145 \\
\hline $\mathbf{a m c}_{\mathbf{t}-3}^{-}$ & 0,2033 & 0,1616 & $-0,5417$ & $0,0559 *$ & 0,0175 & 0,8299 & $-0,1255$ & 0,4873 \\
\hline $\mathbf{a m c}_{\mathbf{t}-4}^{-}$ & 0,1645 & $0,0816^{*}$ & 0,1053 & 0,5581 & $-0,0374$ & 0,4446 & $-0,0797$ & 0,4472 \\
\hline shock $^{+}=0$ & & 0,2328 & & 0,2890 & & $0,0010^{* * *}$ & & 0,9872 \\
\hline $\begin{aligned} \Sigma \text { shock }^{+} & =0 \\
\text { shock }^{-} & =0\end{aligned}$ & $-0,6890$ & $\begin{array}{c}0,0488^{* *} \\
0,5824\end{array}$ & $-1,2157$ & $\begin{array}{c}0,0678^{*} \\
0,2036\end{array}$ & $-0,2222$ & $\begin{array}{l}0,1273 \\
0,5670\end{array}$ & $-0,0769$ & $\begin{array}{c}0,8038 \\
0,0420 * *\end{array}$ \\
\hline$\Sigma$ shock $^{-}=\mathbf{0}$ & 0,2758 & 0,5558 & 1,8671 & $0,0517 *$ & 0,0356 & 0,8634 & $-0,2929$ & 0,5240 \\
\hline shock $^{+}=$shock $^{-}$ & & 0,4221 & & 0,1974 & & 0,4481 & & 0,1217 \\
\hline $\begin{array}{c}\Sigma \text { shock }^{+}= \\
\Sigma \text { shock }^{-}\end{array}$ & & 0,1679 & & $0,0219 * *$ & & 0,3882 & & 0,7418 \\
\hline $\begin{array}{l}\Sigma \text { shock }^{-} \\
\text {amc }^{+}=0\end{array}$ & & 0,1126 & & 0,2922 & & 0,3422 & & 0,6213 \\
\hline $\begin{array}{c}\Sigma \mathrm{amc}^{+}=0 \\
\mathrm{amc}^{-}=0\end{array}$ & 0,7858 & $\begin{array}{c}0,0200^{* *} \\
0,1464\end{array}$ & 0,0717 & $\begin{array}{l}0,9063 \\
0,2177\end{array}$ & $-0,1552$ & $\begin{array}{l}0,4327 \\
0,3365\end{array}$ & $-0,6072$ & $\begin{array}{l}0,1809 \\
0,7962\end{array}$ \\
\hline$\Sigma \mathbf{a m c}^{-}=\mathbf{0}$ & 0,7414 & $0,0152 * *$ & $-0,8630$ & 0,1497 & 0,1334 & 0,4835 & $-0,4916$ & 0,2609 \\
\hline $\mathbf{a m c}^{+}=\mathbf{a m c}^{-}$ & & 0,6630 & & $0,0397 * *$ & & $0,0980^{*}$ & & 0,8077 \\
\hline$\Sigma \mathrm{amc}^{+}=\Sigma \mathrm{amc}^{-}$ & & 0,8467 & & $0,0439 * *$ & & 0,1742 & & 0,8767 \\
\hline $\mathbf{a m c}^{+}=$shock $^{+}$ & & 0,1342 & & 0,4811 & & $0,0026^{* * *}$ & & 0,7909 \\
\hline$\Sigma \mathrm{amc}^{+}=\Sigma$ shock $^{+}$ & & $0,0114 * *$ & & 0,2187 & & 0,7835 & & 0,3535 \\
\hline $\mathbf{a m c}^{-}=$shock $^{-}$ & & 0,5756 & & 0,1467 & & 0,8163 & & $0,0613 *$ \\
\hline$\Sigma \mathrm{amc}^{-}=\Sigma$ shock $^{-}$ & & 0,4328 & & $0,0287 * *$ & & 0,7496 & & 0,7605 \\
\hline $\begin{array}{c}\mathbf{a m c}^{+}=\mathbf{a m c}^{-}= \\
\text {shock }^{+}=\text {shock }^{-}\end{array}$ & & 0,4766 & & 0,1066 & & $0,0072 * * *$ & & 0,3614 \\
\hline $\begin{array}{c}\Sigma \mathrm{amc}^{+}=\Sigma \mathrm{amc}^{-}=\Sigma \\
\text { shock }^{+}=\Sigma \text { shock }^{-}\end{array}$ & & $0,0601 *$ & & $0,0688^{*}$ & & $0,0444 * *$ & & 0,7688 \\
\hline$\sigma$ estimated & & 0,0048 & & 0,0095 & & 0,0023 & & 0,0049 \\
\hline$\overline{\mathbf{R}}^{2}$ & & 0,2706 & & 0,3916 & & 0,7675 & & 0,2646 \\
\hline LB & 18,227 & 0,4407 & 17,617 & 0,4811 & 23,713 & 0,1646 & 14,055 & 0,7254 \\
\hline
\end{tabular}

Equation (6) estimated: $\Delta \mathrm{y}_{\mathrm{t}}=$ constant $+\mathrm{a} \Delta \mathrm{y}_{\mathrm{t}-1}+\sum_{\mathrm{m}=1}^{4} \mathrm{~b}_{\mathrm{m}}^{+} \varepsilon_{\mathrm{t}-\mathrm{m}}^{+}+\sum_{\mathrm{m}=1}^{4} \mathrm{~b}_{\mathrm{t}-\mathrm{m}}^{-} \varepsilon_{\mathrm{t}-\mathrm{m}}^{-}+\sum_{\mathrm{m}=1}^{4} \mathrm{c}_{\mathrm{m}}^{+} \hat{\mathrm{i}}_{\mathrm{t}-\mathrm{m}}^{+}+\sum_{\mathrm{m}=1}^{4} \mathrm{c}_{\mathrm{m}}^{-} \hat{\mathrm{i}}_{\mathrm{t}-\mathrm{m}}^{-}+\mathrm{v}_{4 \mathrm{t}}$ 
Table 7 continuation : Effects of positive/negative and anticipated/unanticipated monetary policy

\begin{tabular}{|c|c|c|c|c|c|c|c|c|}
\hline & \multicolumn{2}{|c|}{ Netherlands } & \multicolumn{2}{|c|}{ Belgium } & \multicolumn{2}{|c|}{ Finland } & \multicolumn{2}{|c|}{ Austria } \\
\hline & Coef. & p-value & Coef. & p-value & Coef. & p-value & Coef. & p-value \\
\hline$\Delta \mathbf{y}_{\mathrm{t}-1}$ & $-0,2921$ & $0,0213 * *$ & 0,0521 & 0,6762 & 0,1688 & 0,1245 & $-0,3074$ & $0,0214 * *$ \\
\hline $\operatorname{shock}_{t-1}^{+}$ & $-0,3285$ & 0,1180 & $-0,1899$ & 0,2849 & $-0,0893$ & 0,7577 & 1,3705 & 0,1263 \\
\hline $\operatorname{shock}_{\mathbf{t}-2}^{+}$ & $-0,2190$ & 0,3181 & $-0,0850$ & 0,6379 & $-0,4481$ & 0,1305 & $-0,7139$ & 0,4676 \\
\hline shock $_{\mathbf{t}-3}^{+}$ & 0,2987 & 0,1983 & 0,1791 & 0,3672 & $-0,4601$ & 0,1609 & $-0,2889$ & 0,7781 \\
\hline $\operatorname{shock}_{\mathbf{t}-4}^{+}$ & $-0,7925$ & $0,0008 * * *$ & $-0,2256$ & 0,2563 & 0,8899 & $0,0068 * * *$ & 0,3481 & 0,7126 \\
\hline $\operatorname{shock}_{\mathbf{t}-1}^{-}$ & 0,5401 & 0,1147 & 0,5190 & $0,0778 *$ & $-0,3233$ & 0,4912 & $-0,2790$ & 0,8298 \\
\hline shock $_{t-2}^{-}$ & $-0,0494$ & 0,9011 & $-0,1149$ & 0,7503 & 1,5043 & $0,0105 * *$ & $-0,7919$ & 0,5973 \\
\hline shock $_{\mathbf{t}-3}^{-}$ & 0,7239 & 0,1745 & 0,8902 & $0,0322 * *$ & $-1,2491$ & $0,0617 *$ & 1,3696 & 0,4512 \\
\hline $\operatorname{shock}_{\mathbf{t}-4}^{-}$ & $-0,1223$ & 0,7971 & $-0,3029$ & 0,4354 & 0,1780 & 0,7871 & $-1,3797$ & 0,4352 \\
\hline $\mathbf{a m c}_{\mathbf{t}-1}^{+}$ & 0,6354 & $0,0074 * * *$ & 0,2694 & 0,1593 & $-0,4078$ & 0,1835 & 0,3233 & 0,6705 \\
\hline $\mathbf{a m c}_{\mathbf{t}-2}^{+}$ & 0,2006 & 0,3598 & $-0,1646$ & 0,3784 & 0,0610 & 0,8377 & 0,3497 & 0,5996 \\
\hline $\mathbf{a m c}_{\mathbf{t}-3}^{+}$ & 0,2175 & 0,3064 & $-0,0614$ & 0,7346 & $-0,2768$ & 0,3459 & 0,0597 & 0,9256 \\
\hline $\mathbf{a m c}_{\mathbf{t}-4}^{+}$ & 0,2469 & 0,1153 & $-0,0998$ & 0,4474 & 0,0918 & 0,6631 & 0,2222 & 0,6853 \\
\hline $\mathbf{a m c}_{\mathrm{t}-1}^{-}$ & 0,1339 & 0,4225 & 0,0433 & 0,7754 & $-0,1400$ & 0,5544 & 0,7211 & 0,2342 \\
\hline $\mathbf{a m c}_{\mathbf{t}-2}^{-}$ & 0,5046 & $0,0695 *$ & 0,2907 & 0,2193 & $-0,2276$ & 0,5497 & 0,1136 & 0,8909 \\
\hline $\mathbf{a m c}_{\mathbf{t}-3}^{-}$ & 0,2663 & 0,3327 & $-0,1249$ & 0,5701 & 0,0667 & 0,8515 & 0,3785 & 0,6572 \\
\hline $\mathbf{a m c}_{\mathbf{t}-4}^{-}$ & $-0,0285$ & 0,8569 & 0,0230 & 0,8621 & $-0,0061$ & 0,9766 & $-0,2210$ & 0,6856 \\
\hline shock $^{+}=0$ & & $0,0069 * * *$ & & 0,5183 & & $0,0215^{* *}$ & & 0,4979 \\
\hline shock $^{+}=0$ & $-1,0413$ & $0,0273 * *$ & $-0,3215$ & 0,3976 & $-0,1077$ & 0,8611 & 0,7158 & 0,7276 \\
\hline shock $^{-}=0$ & & 0,4087 & & 0,1512 & & $0,0671 *$ & & 0,8897 \\
\hline$\Sigma$ shock $^{-}=0$ & 1,0923 & 0,1158 & 0,9914 & $0,0998^{*}$ & 0,1099 & 0,9085 & $-1,0810$ & 0,6756 \\
\hline shock $^{+}=$shock $^{-}$ & & 0,1464 & & 0,2391 & & $0,0236 * *$ & & 0,5936 \\
\hline$\Sigma$ shock $^{+}=$ & & $0,0360 * *$ & & 0,1122 & & 0,8701 & & 0,6377 \\
\hline $\mathrm{amc}^{+}=0$ & & $0,0534 *$ & & 0,2576 & & 0,6251 & & 0,9764 \\
\hline$\Sigma \mathbf{a m c}^{+}=\mathbf{0}$ & 1,3006 & $0,0374 * *$ & $-0,0565$ & 0,9118 & $-0,5317$ & 0,5158 & 0,9550 & 0,6015 \\
\hline $\mathrm{amc}^{-}=\mathbf{0}$ & & 0,3311 & & 0,5561 & & 0,9209 & & 0,7643 \\
\hline$\Sigma \mathrm{amc}^{-}=\mathbf{0}$ & 0,8764 & 0,1687 & 0,2322 & 0,6594 & $-0,3071$ & 0,7110 & 0,9923 & 0,5735 \\
\hline $\mathrm{amc}^{+}=\mathrm{amc}^{-}$ & & 0,1345 & & 0,2391 & & 0,8484 & & 0,9603 \\
\hline$\Sigma \mathrm{amc}^{+}=\Sigma \mathrm{amc}^{-}$ & & $0,0867 *$ & & 0,1122 & & 0,5203 & & 0,9713 \\
\hline $\operatorname{amc}^{+}=$shock $^{+}$ & & $0,0019 * * *$ & & 0,2626 & & $0,0818 *$ & & 0,6252 \\
\hline$\Sigma \operatorname{amc}^{+}=\Sigma$ shock $^{+}$ & & $0,0056 * * *$ & & 0,6878 & & 0,6883 & & 0,9413 \\
\hline $\mathbf{a m c}^{-}=$shock $^{-}$ & & 0,5649 & & 0,2024 & & 0,1041 & & 0,8724 \\
\hline$\Sigma \mathrm{amc}^{-}=\Sigma$ shock $^{-}$ & & 0,8180 & & 0,3959 & & 0,7601 & & 0,5363 \\
\hline $\begin{array}{c}\text { amc }^{+}=\operatorname{amc}^{-}= \\
\text {shock }^{+}=\text {shock }^{-}\end{array}$ & & $0,0249 * *$ & & 0,3128 & & 0,1959 & & 0,9520 \\
\hline $\begin{array}{c}\Sigma \mathrm{amc}^{+}=\Sigma \mathrm{amc}^{-}=\Sigma \\
\text { shock }^{+}=\Sigma \text { shock }^{-}\end{array}$ & & $0,0149 * *$ & & 0,1785 & & 0,8527 & & 0,9300 \\
\hline$\sigma$ estimated & & 0,0070 & & 0,0061 & & 0,0100 & & 0,0284 \\
\hline$\overline{\mathbf{R}}^{2}$ & & 0,3468 & & 0,4526 & & 0,4289 & & 0,1857 \\
\hline LB & 25,968 & 0,1004 & 20,621 & 0,2989 & 25,263 & 0,1178 & 20,483 & 0,3062 \\
\hline
\end{tabular}

Equation (6) estimated: $\Delta \mathrm{y}_{\mathrm{t}}=$ constant $+\mathrm{a} \Delta \mathrm{y}_{\mathrm{t}-1}+\sum_{\mathrm{m}=1}^{4} \mathrm{~b}_{\mathrm{m}}^{+} \varepsilon_{\mathrm{t}-\mathrm{m}}^{+}+\sum_{\mathrm{m}=1}^{4} \mathrm{~b}_{\mathrm{t}-\mathrm{m}}^{-} \varepsilon_{\mathrm{t}-\mathrm{m}}^{-}+\sum_{\mathrm{m}=1}^{4} \mathrm{c}_{\mathrm{m}}^{+} \hat{\mathrm{i}}_{\mathrm{t}-\mathrm{m}}^{+}+\sum_{\mathrm{m}=1}^{4} \mathrm{c}_{\mathrm{m}}^{-} \hat{\mathrm{i}}_{\mathrm{t}-\mathrm{m}}^{-}+\mathrm{v}_{4 \mathrm{t}}$ 


\section{Summary of OLS estimates*}

Table 8: results from equations (3) and (4)

\begin{tabular}{|c|c|c|c|c|c|c|c|c|}
\hline & \multicolumn{2}{|c|}{ Equation (3) } & \multicolumn{6}{|c|}{ Equation (4) } \\
\hline & shock $=0$ & $\Sigma$ shock $=0$ & amc $=0$ & $\Sigma$ amc $=0$ & shock $=0$ & $\Sigma$ shock $=0$ & amc $=$ shock & $\Sigma$ amc $=\Sigma$ shock \\
\hline \multirow{2}{*}{\multicolumn{9}{|c|}{$\begin{array}{c}\text { France } \\
\text { Germany }\end{array}$}} \\
\hline & & & & & & & & \\
\hline \multicolumn{9}{|l|}{ Spain } \\
\hline Italy & & & & & & & & \\
\hline Netherlan & & & & & & & & \\
\hline Belgium & & & & & & & & \\
\hline $\begin{array}{l}\text { Finland } \\
\text { Austria }\end{array}$ & & & & & & & & \\
\hline
\end{tabular}

Table 9: results from equation (5)

\begin{tabular}{|c|l|l|l|l|l|l|}
\hline & shock $^{+}=0$ & $\Sigma$ shock $^{+}=0$ & shock $^{-}=0$ & $\Sigma$ shock $^{-}=0$ & shock $^{+}=$shock $^{-}$ & $\Sigma$ shock $^{+}=\Sigma$ shock $^{-}$ \\
\hline France & & & & & & \\
Germany & & & & & & \\
Spain & & & & & & \\
Italy & & & & & & \\
Netherlands & & & & & & \\
Belgium & & & & & & \\
Finland & & & & & & \\
Austria & & & & & & \\
\hline
\end{tabular}

Table 10: results from equation (6)

\begin{tabular}{|c|c|c|c|c|c|c|c|c|c|c|c|c|c|c|c|c|c|c|}
\hline & shock $^{+}=0$ & $\Sigma$ shock $^{+}=\mathbf{0}$ & shock $=0$ & $\Sigma$ shock $=\mathbf{0}$ & $\begin{array}{c}\text { shock }=\text { =s } \\
\text { hock }^{-}\end{array}$ & $\begin{array}{l}\text { Eshock }{ }^{+}= \\
\Sigma \text { shock }\end{array}$ & $a m c^{+}=0$ & $\Sigma$ amc $^{+}=\mathbf{0}$ & $a m c=0$ & $\Sigma a^{\prime} c^{\circ}=0$ & $\mathrm{amc}^{+}=\mathrm{amc}^{-}$ & $\Sigma \mathrm{amc}^{+}=\Sigma \mathbf{a m c}^{-}$ & amc $^{+}=\operatorname{shock}^{+}$ & $\begin{array}{l}\Sigma \text { amc }^{+}= \\
\Sigma \text { shock }^{+}\end{array}$ & amc $=$choc $^{-}$ & $\begin{array}{l}\Sigma \text { amc= } \\
\Sigma \text { shock }\end{array}$ & $\begin{array}{c}\text { amc }^{+}=\text {amc }^{-}= \\
\text {shock }^{+}=\text {shock }^{-}\end{array}$ & $\begin{array}{c}\Sigma \mathrm{amc}^{+}=\Sigma \mathrm{amc}^{-} \\
=\Sigma \text { shock }^{+}=\Sigma \text { shock }^{-}\end{array}$ \\
\hline \\
\hline \multirow{2}{*}{\multicolumn{19}{|c|}{ Germany }} \\
\hline & \multicolumn{18}{|c|}{ Spain } \\
\hline \multirow{2}{*}{\multicolumn{19}{|c|}{$\begin{array}{c}\text { Italy } \\
\text { Netherlands }\end{array}$}} \\
\hline & & & & & & & & & & & & & & & & & & \\
\hline \multicolumn{12}{|c|}{ Belgium } & & & & & & & \\
\hline Finland & & & & & & & & & & & & & & & & & & \\
\hline Austria & & & & & & & & & & & & & & & & & & \\
\hline
\end{tabular}

* The greyed cells correspond to rejection of the null hypothesis tested, 


\section{Summary of results estimated by NLGLS*}

Table 11: results from equation (5)

\begin{tabular}{|c|l|l|l|l|l|l|}
\hline & shock $^{+}=0$ & $\Sigma$ shock $^{+}=0$ & shock $^{-}=0$ & $\Sigma$ shock $^{-}=0$ & shock $^{+}=$shock $^{-}$ & $\Sigma$ shock $^{+}=\Sigma$ shock $^{-}$ \\
\hline France & & & & & & \\
Germany & & & & & & \\
Spain & & & & & & \\
Italy & & & & & & \\
Netherlands & & & & & & \\
Belgium & & & & & \\
Finland & & & & & & \\
Austria & & & & & & \\
\hline
\end{tabular}

Table 12: results from equation (6)

\begin{tabular}{|c|c|c|c|c|c|c|c|c|c|c|c|c|c|c|c|c|c|c|}
\hline & shock $^{+}=0$ & $\Sigma$ shock $^{+}=0$ & shock $=0$ & $\Sigma$ shock $^{\circ}=0$ & $\begin{array}{c}\text { shock }^{+}= \\
\text {shock }\end{array}$ & $\begin{array}{l}\Sigma \text { shock }^{+}= \\
\Sigma \text { shock }\end{array}$ & $\mathrm{amc}^{+}=0$ & $\Sigma \mathrm{amc}^{+}=\mathbf{0}$ & amc $=0$ & $\Sigma a m c=0$ & $\mathrm{amc}^{+}=\mathrm{amc}^{-}$ & $\begin{array}{l}\Sigma \mathrm{amc}^{+}= \\
\Sigma \mathrm{amc}^{-}\end{array}$ & amc $^{+}=$shock $^{+}$ & $\begin{array}{l}\Sigma \text { amc }^{+}= \\
\Sigma \text { shock }^{+}\end{array}$ & amc $^{-}=$shock $^{-}$ & $\begin{array}{l}\Sigma \text { amc }= \\
\Sigma \text { shock }\end{array}$ & $\begin{array}{c}\begin{array}{c}\text { amc }^{+}=\text {amc }^{-} \\
=\text {shock }^{+}=\text {shock }^{-}\end{array} \\
\end{array}$ & $\begin{array}{c}\sum \mathrm{amcc}^{+}=\Sigma \mathrm{amcc}^{-} \\
=\Sigma \text { shock }^{+}=\Sigma \text { shock }^{-}\end{array}$ \\
\hline \\
\hline \multicolumn{19}{|l|}{ Germany } \\
\hline \multicolumn{19}{|l|}{ Spain } \\
\hline \multicolumn{19}{|l|}{ Italy } \\
\hline \multicolumn{19}{|c|}{ Netherlands } \\
\hline \multicolumn{19}{|l|}{ Belgium } \\
\hline Finland & & & & & & & & & & & & & & & & & & \\
\hline Austria & & & & & & & & & & & & & & & & & & \\
\hline
\end{tabular}

* The greyed cells correspond to rejection of the null hypothesis tested, 